\title{
MANAGERIAL INVESTMENT AND CHANGES IN GAAP: AN INTERNAL CONSEQUENCE OF EXTERNAL REPORTING
}

\author{
by \\ Nemit Omprakash Shroff \\ A dissertation submitted in partial fulfillment \\ of the requirements for the degree of \\ Doctor of Philosophy \\ (Business Administration) \\ in The University of Michigan \\ 2011
}

Doctoral Committee:

Associate Professor Michelle L. Hanlon, Co-Chair, MIT

Professor Russell J. Lundholm, Co-Chair

Professor Raffi J. Indjijekian

Associate Professor Amy K. Dittmar

Associate Professor Gregory S. Miller

Assistant Professor Yusuf Can Masatlioglu 
(C) Nemit Omprakash Shroff 2011 


\section{DEDICATION}

I dedicate this dissertation to my wife, Niketa, to my parents, Omprakash and Ranna Shroff, to my sister Nitte Bagaria and my cousins, Anoop and Minal Shroff - all of whom encouraged and supported me through the Ph.D. process. 


\section{ACKNOWLEDGEMENTS}

This dissertation is the culmination of my interactions with many people who have impacted my thinking over the years - indeed too many to list. However, a number of individuals have significantly influenced this document. First, I would like to thank my Co-Chairs, Michelle Hanlon and Russell Lundholm, for all of their suggestions, advice and encouragement throughout the dissertation process. Additionally, the guidance of the members of my committee - Raffi Indjijekian, Gregory Miller, Amy Dittmar, and Yusufcan Masatlioglu - has been simply invaluable.

I am also grateful to Feng Li for help and guidance at the preliminary stages of the project and Beth Blankespoor and Hal White for their support, comments, and the numerous discussions throughout the writing of this dissertation. I have also benefited from conversations with and feedback from S.P. Kothari, Bill Lanen, Roby Lehavy, Michal Matejka, Mike Minnis, Venky Nagar, Cathy Shakespeare, Terry Shevlin, Joseph Weber, Chris Williams, Gwen Yu and Jerry Searfoss. I have benefited greatly from the Ph.D. students at the University of Michigan who have helped me get through the Ph.D. process.

I am very grateful to my wife, Niketa, who supported me throughout the

dissertation process. I must also acknowledge the support from my family back in India. Without them, this would not have been possible. 
I thank Ryan Hill, Arkisha Howard, Peter Lundholm, Paul Michaud, and Niketa Shroff for help with data collection. I thank Peter Demerjian for providing me data to link Dealscan with Compustat.

Finally, I gratefully acknowledge financial support from the Paton Accounting Fellowship and the Deloitte Fellowship. 


\section{TABLE OF CONTENTS}

DEDICATION $\quad$ ii

ACKNOWLEDGEMENTS

LIST OF TABLES vii

LIST OF APPENDICES viii

ABSTRACT ix

CHAPTER

1. Introduction 1

2. Prior Literature, Motivation, and Hypotheses 10

2.1 Information, Changes in GAAP, and Managerial Investment 10

2.2 Contracting outcomes, Changes in GAAP, and Managerial Investment 13

2.3 Hypotheses 14

3. Variable Measurement 20

3.1 Measuring Investment and the Determinants of Investment 20

3.2 Measuring Changes in Investment Efficiency 21

3.3 Identifying Changes in GAAP 23

3.4 Measuring the Likelihood that a Change in GAAP Informs Managers $\quad 24$

3.5 Measuring Debt Contracting Incentives 26 
4. Data and Sample Selection 28

5. Research Design and Empirical Analyses 31

5.1 Summary Statistics and Correlations 31

5.2 Regression Analysis - Test of H1 33

5.3 Regression Analysis - Tests of H2a, H2b, and H3 36

5.4 Regression Analysis - Tests of H4 41

6. Identification and Endogeneity Concerns 45

7. Additional Analyses and Robustness Checks 49

7.1 Simultaneously Testing both Information and Contracting Hypotheses 49

7.2 The Tobit Model 50

7.3 Accounting Standards Classification $\quad 52$

7.4 Other Sensitivity Tests

8. Conclusion $\quad 54$

TABLES

$\begin{array}{ll}\text { APPENDICES } & 70\end{array}$

$\begin{array}{ll}\text { BIBLIOGRAPHY } & 78\end{array}$ 


\section{LIST OF TABLES}

\section{TABLE}

4.1 Sample Selection

5.1 Descriptives details of the changes in GAAP

5.2 Summary Statistics of Variables used in the Regression Analysis

60

5.3 Univariate Correlations

5.4 Regression Analysis: Tests of Hypothesis One

5.5 Regression Analysis: Tests of Hypothesis Two, Part A

5.6 Regression Analysis: Tests of Hypothesis Two, Part B

5.7 Regression Analysis: Tests of Hypothesis Three

5.8 Regression Analysis: Main Tests of Hypothesis Four

5.9 Regression Analysis: Additional Tests of Hypothesis Four

7.1 Robustness Tests

69 


\section{LIST OF APPENDICES}

\section{APPENDIX}

A. Identifying Changes in GAAP that are likely to inform Managers 70

B. Variable Definitions 


\begin{abstract}
Managerial Investment and Changes in GAAP: An Internal Consequence of External Reporting

by
\end{abstract}

Nemit Omprakash Shroff

Co-Chairs: Michelle L. Hanlon and Russell J. Lundholm

This paper investigates whether mandatory changes in Generally Accepted Accounting Principles (GAAP) affect investment in physical capital and research and development. Using a sample containing forty-nine changes in GAAP, I find evidence that changes in accounting rules affect investment decisions. I then examine two mechanisms through which changes in GAAP affect investment. First, I show that the process of complying with certain mandatory changes in financial reporting alters managers' information sets and consequently changes the quality of their investment decisions. Second, I show that firms with financial covenants likely to be affected by changes in GAAP invest more (less) when the change in GAAP increases (decreases) covenant slack. This paper contributes to the literature on the real effects of accounting by showing that accounting rules affect investment decisions and by documenting specific mechanisms through which the relation manifests. 


\section{CHAPTER 1}

\section{Introduction}

In this paper, I investigate whether changes in Generally Accepted Accounting Principles (GAAP) affect an important managerial decision - corporate investment. Further, I investigate two mechanisms through which this relation manifests. First, I put forward and examine a novel reason why changes in GAAP might affect investment. I argue that changes in GAAP can force managers to collect and process additional information to comply with the new standard, which changes their information set and their subsequent decisions (henceforth, I refer to this proposed mechanism as the "information hypothesis"). Second, I examine whether changes in GAAP affect investment decisions when accounting numbers are used to compute covenants in private debt agreements. Financial accounting statements based on GAAP serve as the foundation for

contracting on accounting information (Leftwich, 1983). Therefore, when contracts do not provide for a course of action in the event of a change in GAAP, and contract renegotiation is costly, the change in GAAP can affect the real decisions of firms participating in these contracts (Holthausen and Leftwich, 1983; Watts and Zimmerman, 1986; henceforth, I refer to this proposed mechanism as the "contracting hypothesis"). 
The information hypothesis is predicated on the observation that managers have limited attention and are unlikely to process all the information available within the firm. Supporting the idea that managers have limited attention, Simon (1973) argues that, "...the scarce resource is not information; it is processing capacity to attend to information. Attention is the chief bottleneck...and the bottleneck becomes narrower and narrower as we move to the tops of organizations..." When attention is a bottleneck, managers might find it costly to maintain separate accounting systems for internal and external reporting. For example, when internal and external accounting systems report different numbers for the same concept, confusion arises as to which system is producing the "right" number (Zimmerman, 2009; pg. 7). As a result, firms often generate internal accounting reports using GAAP as the foundation for measurement. ${ }^{1}$

Managers relying on closely aligned accounting systems for external reporting and internal decision making may fail to recognize some of the deficiencies of using GAAP for internal decisions. Consequently, some changes in GAAP that obligate managers to collect and process additional information to implement the new rule can incrementally inform managers about the future cash flow consequences of their decisions. For example, Singh (2001) quoted Ben Neuhausen, a partner in Arthur Andersen's professional standards group, as saying, "I think some companies were genuinely clueless about how much these benefits were going to cost them over the long haul...once Statement 106 [post retirement benefits] forced them to measure these obligations, a lot of companies realized that they had offered benefits they could not afford.” Therefore, the process of complying with some

\footnotetext{
${ }^{1}$ See Ball (2004) for anecdotal evidence. Hopper et al. (1992) and Drury and Tayles (1997) provide survey evidence.
} 
accounting standards can inform managers that they under- or over-estimated the future cash flow consequences of their decisions. I hypothesize that changes in GAAP that inform managers that they overestimated (underestimated) the future cash flows and net present values (NPV) of their investment decisions cause managers to decrease (increase) investment. ${ }^{2}$ In addition, if changes in GAAP inform managers, they are likely to improve managerial investment decisions by reducing the likelihood of investing in negative NPV projects, and increasing the likelihood of investing in positive NPV projects.

The contracting hypothesis begins with the argument that because the numbers reported in financial statements have a direct bearing on institutional arrangements and contractual outcomes, managers pay close attention to the impact their actions have on financial statements. Consequently, if an accounting change significantly alters firms' financial statements but contracts are not fully adjusted to accommodate such a change, managers will be inclined to alter their actions (Holthausen and Leftwich, 1983). For example, debt contracts often contain covenants based on numbers reported in financial statements (Smith and Warner, 1979). The covenants in these contracts make it desirable for firms to report higher earnings and book equity (Watts and Zimmerman, 1986). When a change in GAAP has an unfavorable (favorable) impact on current and future financial statements, and debt covenants are not adjusted to incorporate the changes, the change in GAAP will likely tighten (loosen) covenant slack. Consequently, the change in slack may

\footnotetext{
${ }^{2}$ For example, if the adoption of SFAS 106 informed managers that they overestimated the NPV of existing investments by underestimating the cost of employees, this information is likely to cause a downward revision in NPV estimates and thus, turn some previously positive NPV projects into negative NPV projects. Any such change in managerial NPV estimates is likely to decrease total investment. However, it is also conceivable that managers shift resources away from investments whose NPV is revised downward to other investments that are relatively more attractive in light of the information obtained from the change in GAAP. Therefore, changes in GAAP might be unrelated to total investment.
} 
cause a decrease (increase) in any discretionary spending that increases the probability of obtaining an unfavorable financial statement outcome.

I test whether changes in GAAP affect managerial investment using a sample containing forty-nine mandatory accounting rule changes implemented between 1991 and 2007. I measure investment as research and development (R\&D) and capital expenditures, and I use the cumulative effect of an accounting change to measure the impact an accounting rule change has on firms' earnings and book equity. ${ }^{3}$ An innovation of my setting is that I use multiple accounting changes spread over 17 years, which enables me to control for accounting standard fixed effects and mitigate concerns that the results are driven by idiosyncratic attributes of a standard or the economic conditions around the adoption of any single standard (Ball, 1980).

I begin my analysis by testing whether the cumulative effect of an accounting change is related to managerial investment decisions after controlling for other determinants of investment. The cumulative effect captures both the magnitude and sign of the impact an accounting change has on firms' financial statements, thus if changes in GAAP affect managerial investment then I expect the cumulative effect to be positively related to investment under either hypothesis. Specifically, negative cumulative effects may inform managers that they overestimated profits and cause them to revise NPV estimates downward, leading to a decrease in investment (and vice versa for positive cumulative effects). Alternatively, managers might cut investment because the cumulative effect has an

\footnotetext{
${ }^{3}$ The cumulative effect of an accounting change is a one-time, non-cash, below-the-line charge reflecting the catch up effect from adopting the new accounting rule. The cumulative effect captures the difference between the old and new accounting practice as well as the degree to which a firm uses the economic transaction for which the accounting changed.
} 
unfavorable impact on financial statements, which increases the probability of obtaining an unfavorable contractual outcome (and vice versa for positive cumulative effects). I find evidence consistent with my overall research question - the cumulative effect of an accounting change is positively related to both capital and $R \& D$ investments, evidence that changes in GAAP affect managerial investment decisions.

To identify whether the relation between changes in GAAP and investment is explained by one or both - information and contracting - hypotheses, I exploit the variation in the nature of the changes in GAAP. In particular, I classify the standards into two groups based on their likelihood of providing managers with information. ${ }^{4}$ The contracting hypothesis suggests a positive relation between the cumulative effect and investment for all changes in GAAP that alter contractual outcomes by changing the manner in which financial statements are prepared. However, the information hypothesis suggests that the relation between the cumulative effect and investment is restricted to the cumulative effects arising from changes in GAAP that are likely to inform managers. Further, the information hypothesis predicts an improvement in the quality of managerial investment decisions (i.e., investment efficiency) following changes in GAAP that are likely to inform managers. In contrast, the contracting hypothesis makes no prediction about investment efficiency.

I find that the relation between the cumulative effect of an accounting change and investment is positive and statistically significant when the change in GAAP is likely to

\footnotetext{
${ }^{4}$ The classification of change in GAAP as more or less likely to inform managers is based on my subjective assessment of the accounting standard's likelihood of informing managers. I validate this measure using a returns based test described in section 3.4, and I discuss the rationale for each classification choice in Appendix A.
} 
inform managers; the relation is insignificant otherwise. I also find that investment efficiency improves following changes in GAAP that are more likely to inform managers. Both findings suggest that changes in GAAP can provide managers with information and facilitate their investment decisions.

To substantiate my inference and move away from the subjective classification of accounting standards, I investigate whether firms with diverse operations (measured by the Herfindahl index for diversification following Bushman et al., 2004) derive larger benefits from any information realized from changes in GAAP. The premise for this test is that diverse operations reduce top management focus and exacerbate problems associated with limited attention. Therefore, there is a greater likelihood that managers of diversified firms neglect some information relevant for decision making, and that a change in GAAP informs them. Consistent with this prediction, I find that the improvement in investment efficiency is greater for diversified firms. Collectively, these results suggest that some changes in GAAP can inform managers and improve their investment decisions.

The tests thus far provide limited support for the contracting hypothesis. To investigate further, I examine the contracting hypothesis in a setting where managers are more likely to be concerned about contracting outcomes. It is plausible that managers on average do not change long-term investment behavior to affect contracting outcomes due to changes in GAAP because managers have other perhaps less costly mechanisms through which they can alter contracting outcomes in the short run (e.g., accrual manipulation, altering operating activities, etc.). Therefore, I examine whether firms with covenants in private debt agreements are more likely to change investment in response to a change in 
GAAP. ${ }^{5}$ Most investments have an uncertain future outcome and some positive probability that the outcome is a loss. Therefore, such investments increase the probability of violating covenants in the future by adversely impacting future financial ratios. As a result, a decrease in covenant slack increases the probability of violating covenants, to which managers might respond by cutting investment in risky assets with the goal of preserving net worth and preventing deterioration of financial ratios.

I find that changes in GAAP affect both capital and $R \& D$ investments in the presence of financial covenants. Additional tests reveal that changes in GAAP affect investment via its effect on covenants only for the subset of firms whose debt contracts allow changes in GAAP to affect covenant slack (i.e., when contracts are based on floating GAAP). In contrast, when debt contracts explicitly disallow accounting changes from influencing the computation of covenants, I find that the relation between changes in GAAP and investment is statistically insignificant. I also find that changes in GAAP have a larger impact on investment when borrowers are likely to find renegotiating the debt contract costly, where renegotiation costs are measured by the change in firm performance. These results suggest that changes in GAAP affect managerial investment decisions not only by changing managerial information sets but also by altering contracting outcomes.

This paper makes several contributions to the accounting and finance literatures. First, I provide direct evidence that changes in GAAP affect managerial investment

${ }^{5}$ Contracting concerns are likely to play an important role in determining managerial actions also when accounting numbers are used in compensation contracts or for regulatory purposes. However, prior research suggests that managerial compensation contracts are often adjusted following changes in GAAP (e.g., Gaver and Gaver, 1998). I do not examine whether regulatory uses of accounting numbers cause changes in GAAP to affect managerial actions because the majority of industrial firms are unaffected by such regulation. Moreover, prior research provides convincing evidence that changes in GAAP have real effects in such settings (e.g., Bens and Monahan, 2008). However, there is limited evidence that changes in GAAP have real effects in other settings (Beatty, 2007). 
decisions. Prior research on the relation between accounting changes and economic behavior examine whether accounting for a transaction has real effects on that particular transaction for which the accounting changed. For example, Mittelstaed et al. (1995) show that the change in accounting for post retirement benefits (SFAS 106) leads to a reduction in post retirement benefits offered to employees. In contrast, I show that accounting rules have a more fundamental impact on investment decisions even when the accounting rule change is unrelated to the measurement and reporting of managerial investment decisions. Second, I show that the process of complying with certain mandatory changes in financial reporting alters managers' information set, and consequently the quality of their investment decisions. This internal information effect is largely unexplored by prior financial reporting studies that take the managers' information set as constant when examining how changes in reporting rules affect outside investors' information sets.

Third, this paper contributes to a recent stream of research in finance that examines the relation between investment and financial contracting. In a related study, Chava and Roberts (2008) show that capital investment declines sharply following a financial covenant violation, when creditors use the threat of accelerating the loan to intervene in management. Nini et al. (2009) find that debt contracts often contain capital expenditure restrictions, especially when credit quality deteriorates, which causes a reduction in investment. These studies show that financial contracting imposes a direct cost on firms by constraining investment when firm performance declines. My paper builds on this line of research by showing that even non-performance related increases in the probability of 
violating covenants due to changes in GAAP can cause managers to cut investment - an indirect cost of financial contracting.

Lastly, this paper contributes to a growing body of research that shows that financial reporting considerations are associated with managerial investment decisions. ${ }^{6}$ These studies identify settings where accounting information is more likely to affect contracting outcomes or investor perceptions to examine the link between accounting and investment. A potential issue with these studies, which these studies fully acknowledge, is that firms' investment decisions and reporting choices are endogenous (e.g., see Murphy and Zimmerman (1993) and Fields et al. (2001) for discussions of the endogeneity concern). By studying changes in firm behavior around the adoption of multiple new standards, this paper adds evidence on the link between accounting and investment in a completely different setting that is less likely to be confounded by simultaneity bias.

The rest of the paper proceeds as follows. The next chapter discusses prior research and develops the hypotheses. Chapter 3 discusses the variables. Chapter 4 describes the data. Chapter 5 discusses the research design and empirical results. Chapter 6 addresses identification and endogeneity concerns. Chapter 7 discusses additional analyses, and Chapter 8 concludes.

\footnotetext{
${ }^{6}$ See e.g., Dechow and Sloan (1991), Bushee (1998), Bens et al. (2002), McNichols and Stubben (2008), Jackson et al. (2009), and Graham et al. (2010).
} 


\section{CHAPTER 2}

\section{Prior Research, Motivation, and Hypotheses}

\subsection{Information, Changes in GAAP, and Managerial Investment}

One of the primary objectives of financial reporting is to provide investors with information to estimate firms' future cash flows and facilitate investors' capital allocation decisions (Beaver, 1981; Kothari et al., 2010). ${ }^{7}$ Managers make capital allocation decisions by forecasting and discounting future cash flows from investments (Graham and Harvey, 2001). Therefore, the production of financial accounting statements for external investors can have a spillover effect on managers' information sets by requiring managers to assimilate information to comply with financial accounting rules - rules that are partly designed to help forecast firms' future cash flows. However, managers have virtually unconstrained access to all information within the firm on a more timely basis and in greater detail than that reported in financial statements. ${ }^{8}$ If the costs of compiling and processing information are low, managers should be able to obtain any information relevant for decision making.

\footnotetext{
${ }^{7}$ Financial Accounting Standards Board (FASB) in their statement of concepts (SFAC No. 1, highlights) state that "[f]inancial reporting should provide information to help present and potential investors and creditors and other users in assessing ... prospective cash receipts ... Since investors' and creditors' cash flows are related to enterprise cash flows, financial reporting should provide information to help investors, creditors, and others assess the amounts, timing, and uncertainty of prospective net cash inflows to the related enterprise."

${ }^{8}$ Revsine et al. (1999) claim that "...managers regularly make operating and financing decisions based on information that is much more detailed and timely than the information found in financial statements..."
} 
Although managers have unconstrained access to information within the firm, theories of costly information acquisition and processing suggest that managers have limited information processing capacities and are unlikely to be cognizant of all the possible information relevant for decision making (Simon, 1973; Sims, 2003). When regulators change accounting rules with the stated objective of improving the ability of financial statements to forecast future cash flows, the accounting change might inform managers about the cash flow consequences of their actions and thus facilitate their decisions.

Changes in GAAP can affect managerial information sets for two reasons. First, simply the act of presenting information in public financial statements can cause managers to pay closer attention to it. Public financial statements are closely scrutinized by the entire investing community and the press, which creates incentives for managers to closely monitor the information in financial statements. Therefore, a change in reporting requirements can alert managers to unused information, which can cause them to revise investment decisions. Second, the process of complying with a new accounting rule can cause firms to gather additional data within the firm, which might improve managerial estimates of future cash flows. For example, compliance with standards such as SFAS 106 (post retirement benefits), SFAS 112 (post employment benefits), SFAS 142 (goodwill), and SFAS 143 (asset retirement obligation) among others require firms to hire outside experts (e.g., actuaries, appraisers, etc.) to help managers estimate accruals and evaluate the value of 
assets/liabilities. Therefore, such changes in GAAP can improve the quality of the information available to managers to make their investment decisions. ${ }^{9,10}$

Supporting the argument that changes in accounting rules affect managerial information sets, anecdotal and survey evidence show that financial accounting rules affect management information systems - the premier source of information for managerial decision making. ${ }^{11}$ Conventional wisdom claims that managerial and financial accounting are fundamentally different entities since they cater to fundamentally different audiences. However, Zimmerman (2009; pg. 7) argues that using different systems for managerial decision making and external reporting can be costly because managers have limited information processing capacities and the different systems can create disorder when they report different numbers for the same concept. Besides, maintaining a similar accounting system for internal and external reporting has other benefits such as a lower cost of auditing the system. In such a scenario, changes in financial reporting rules can affect internal information systems and thus provide managers with new information, which facilitates their investment decisions.

\footnotetext{
${ }^{9}$ It is important to note that I do not make any assumption about the quality of the new standard and its de facto effect on the ability of financial statements to forecast cash flows.

${ }^{10}$ Hemmer and Labro (2008) argue that changes in financial reporting rules affect the optimal precision of the management accounting system and hence, the quality of managerial investment decisions. Their model relies on the observation that information asymmetry between managers and outsiders is affected by the quality of both the financial and management reporting system in place. By changing the amount of information asymmetry between managers and investors, changes in financial reporting rules lead to changes in the quality of the management information systems and subsequent management decisions. Although I do not explore this mechanism in detail, I control for the changes in the quality of information received by outsiders and hence, any change in information asymmetry due to the accounting change.

${ }^{11}$ See e.g., Kaplan (1984), Johnson and Kaplan (1987), Hopper et al. (1992), Drury and Tayles (1997), and Ball (2004).
} 


\subsection{Contracting Outcomes, Changes in GAAP, and Managerial Investment}

Accounting numbers prepared under GAAP serve as a foundation for contracting on accounting information (Leftwich, 1983). As a result, changes in GAAP can affect real decisions through their effect on contractual outcomes and managerial incentives (Holthausen and Leftwich, 1983; Watts and Zimmerman, 1986). ${ }^{12}$ Holthausen and Leftwich (1983) discuss that in the presence of incomplete contracts and transaction costs it can be difficult to alter institutional arrangements to accommodate a change in accounting rules. Consequently, changes in GAAP can have economic consequences by altering the distribution of firms' cash flows or the wealth of contracting parties.

Following this line of reasoning, some studies examine firms' responses to mandatory changes in GAAP. For example, Beatty (1995) and Hodder et al. (2002) show that the implementation of SFAS 115, which requires certain debt and equity investment securities to be fair valued, led banks to change the size and composition of their investment securities portfolio. Both studies suggest that changes to the banks regulatory capital ratio is the principle cause for the change in firm behavior. Mittelstaedt et al. (1995) document a reduction in retiree healthcare benefits after SFAS 106 changed the accounting for postretirement benefits. They find that higher debt contracting costs are the primary reason for the reduction in postretirement benefits. ${ }^{13}$ In studies more focused on managerial investment and contracting, Bens and Monahan (2008) and Zhang (2009)

\footnotetext{
${ }_{12}$ Prior studies document stock market reactions to changes in the probability that a new accounting pronouncement will become mandatory (see e.g., Collins et al., 1981; Leftwich, 1981; Lys, 1984; and Christensen et al., 2009). These papers interpret the relation between mandatory accounting changes and stock returns as evidence that accounting changes alter firms' financing and investment behavior in the presence of accounting based contracts.

${ }^{13}$ Also see Imhoff and Thomas (1988), Marquardt and Wiedman (2005), and Choudhary et al. (2009) among others.
} 
provide evidence that the introduction of FIN 46 (consolidation of variable interest entities) led firms to cut investments in variable interest entities. They attribute the decrease in such investments to the U.S. bank regulator's use of GAAP accounting numbers to evaluate the capital adequacy of banks. Bens and Monahan (2008) conclude that "in certain settings, accounting standards appear to have real effects on investment activity..."

A common theme among prior studies that examine the real effects of changes in GAAP is that they focus on whether accounting for a specific economic transaction (e.g., retirement benefits) affects the future use of that economic transaction (e.g., providing employees retirement benefits). I build on these studies by examining whether changes in GAAP have a more general effect on capital and $R \& D$ investment decisions even when the accounting rules for capital and $R \& D$ investment remain constant. This examination broadens the economic implications of changes in accounting rules (due to incomplete contracting) beyond the direct effect of the accounting change.

\subsection{Hypotheses}

I conjecture that changes in GAAP that have a positive (negative) impact on current and future financial statements are likely to have two effects. First, they inform managers that they underestimated (overestimated) the NPV of their investments. I assume that changes in GAAP that inform and cause managers to revise NPV estimates have a homogenous effect on the NPV estimates of all available investment opportunities. That is, changes in GAAP either inform managers that they underestimated the NPV of all 
available investment opportunities or that they overestimated the NPV of all available investment opportunities. ${ }^{14}$ Therefore, changes in GAAP that inform managers that they underestimated (overestimated) project NPV are likely to be followed by an increase (decrease) in investment. Second, I conjecture that changes in GAAP that have a negative (positive) impact on financial statements are likely to increase the probability of having a negative (positive) contracting outcome and, managers are likely to respond to such changes in GAAP by cutting investment in risky assets with the goal of preventing further deterioration of financial ratios in the future.

H1: The cumulative effects of accounting changes are positively associated with firms' investment.

To examine whether changes in GAAP affect managerial investment by informing managers and/or by altering contractual outcomes, I exploit variation in the likelihood that a change in GAAP informs managers. Changes in GAAP that increase the amount of accrual accounting estimates are more likely to inform managers because they might impose additional information processing requirements on managers to arrive at reasonable accrual estimates. For example, compliance with some standards such as SFAS 106 (post retirement benefits) and SFAS 142 (goodwill impairment) require firms to make considerable judgments about future events to arrive at reasonable estimates of the expense/benefit and the value of the asset/liability. Making informed estimates requires information which may or may not be readily available to managers. Further, even if the

\footnotetext{
${ }^{14}$ Note that it is conceivable that a change in GAAP informs managers that they underestimated the NPV of some investment opportunities but not of others. In such a scenario, changes in GAAP can cause managers to substitute away from investments whose NPV is revised downward and invest in other projects whose NPV is unchanged and hence, relatively better after the change in GAAP. Therefore, a change in GAAP can have an ambiguous effect on the total investment of a firm without the assumption of homogeneity. I relax this assumption for hypotheses $2 \mathrm{~b}$ and 3 .
} 
information necessary to comply with new standards is readily available, managers are likely to pay more attention to their accrual estimates when it is being reported to the public. Therefore, such standards are more likely to inform managers.

On the other hand, compliance with rules such as SFAS 123R (expensing stock options), SOP 98-5 (mandatory expensing of business startup costs), and SAB 101 (revenue recognition) are less likely to provide managers with decision-facilitating information. SAB 101, for example, increased verifiability requirements to recognize revenue, which primarily resulted in postponing revenue recognition until the higher verifiability threshold is met (Altamuro et al., 2005). Since managers are less likely to gain any information about the underlying cash flow stream from a higher verifiability threshold, this standard is less likely to inform managers.

The information hypothesis predicts that firms adopting accounting changes that are more likely to inform managers will alter and improve managerial investment decisions. Conceptually, an improvement in managerial investment entails undertaking projects with positive NPV and avoiding projects with negative NPV (Brennan, 2003). Since a key determinant of successful capital allocation is the precision with which managers identify the NPV of investments, changes in GAAP that improve managers' NPV estimates should also improve investment efficiency. The contracting hypothesis makes no prediction about investment efficiency. The above discussion leads to the following hypotheses:

H2a: The cumulative effects of accounting changes are positively associated with firms' investment when the accounting change is more likely to inform managers about the profitability of current or future projects. 
$\mathrm{H} 2 \mathrm{~b}$ : The magnitude of the cumulative effect of an accounting change is positively associated with changes in investment efficiency when the accounting change is more likely to inform managers about the profitability of current or future projects.

To further examine the information hypothesis, I investigate cross-sectional variation in the relation between changes in GAAP and investment efficiency based on the level of diversification of firms. Firms with diverse operations face more complex information environments and potentially derive more benefit from any new information that might be realized from changes in GAAP relative to firms with tighter operating focus. Specifically, multi-segment firms confront the possibility that diverse activities reduce top management focus and exacerbate problems associated with limited attention. Further, combining diverse operations creates information aggregation problems that can result in information asymmetries within the firm (Bushman et al., 2004). Therefore, I also examine whether the relation between changes in GAAP and investment efficiency is affected by the complexity of the firm's internal information environment.

H3: The association between the magnitude of the cumulative effect of an accounting change and changes in investment efficiency is stronger for firms with more complex internal information environments.

Finally, I hypothesize that changes in GAAP affect managerial investment decisions by altering the probability of violating debt covenants in the future. Financial covenants in private debt agreements provide a good setting to examine the effects of changes in GAAP on investment because of their ubiquity and because covenants are generally defined in terms of modified versions of GAAP (Smith and Warner, 1979). Further, since the 
covenants in private credit agreement are tightly set, even small changes in financial ratios are likely to affect firm behavior (Kahan and Tuckman, 1993; Verde, 1999; Dichev and Skinner, 2002). Therefore, when a change in GAAP pushes firms closer to (away from) covenant violation, firms are likely to respond by cutting (increasing) investment spending, provided the covenants are not fully adjusted to undo the effect of the change in GAAP.

H4: The cumulative effects of accounting changes are positively associated with firms' investment when firms have financial covenants that are affected by the change in GAAP.

Ex ante, it is uncertain whether changes in the probability of covenant violation due to mandatory accounting changes will cause managers to alter investment. Financial covenants are generally put in place to monitor managers and prevent them from taking actions that transfer wealth from debt holders to equity holders (Tirole, 2006). Since firms do not have a choice but to adopt mandatory changes in GAAP, debt holders are likely to be more willing to renegotiate debt contracts to accommodate changes in GAAP. Therefore, any costs of violating financial covenants due to mandatory changes in GAAP are indirect costs of financial covenants which may or may not be large enough to warrant a change in managerial investment. ${ }^{15}$ Moreover, managers have other mechanisms through which they can alter contracting outcomes in the short run. For example, prior research suggests that managers manipulate accruals (Healy and Wahlen, 1999; Dechow and Skinner, 2000), cash flows (Lee, 2010), and day-to-day operations (Roychowdhury, 2006; Cohen et al.,

\footnotetext{
${ }^{15}$ Even the direct costs of violating covenants such as increased interest rates, faster loan repayment, etc. are not always very high (see Armstrong et al. (2010) for a review of the literature). If the threat of violating covenants is sufficiently unlikely or if renegotiation costs are expected to be low as in the case of mandatory changes in GAAP, managers are unlikely to change investment decisions in response to a change in the probability of violating covenants.
} 
2009) to achieve the desired financial reporting outcomes. Given these alternatives, whether managers change long-term investment to lower the probability of an adverse accounting outcome and the resultant contracting outcome is an empirical question. 


\section{CHAPTER 3}

\section{Variable Measurement}

The five primary variables used to test my hypotheses include 1) investment and its determinants, 2) changes in investment efficiency, 3) impact of changes in GAAP on firms' financial statements, 4) the likelihood that a change in GAAP provides managers with new information, and 5) managers' debt contracting incentives to modify behavior. I describe the measurement of these variables below.

\subsection{Measuring Investment and the Determinants of Investment}

I measure Investment as either capital or $R \& D$ expenditure. ${ }^{16}$ I assume that $R \& D$ expenditure is zero when it is missing in Compustat. The determinants of investment include: Tobin's Q, Growth, Age, MVE, CFO, Cash, Leverage, Returns, and lagged Investment. Tobin's $\mathrm{Q}$ is the sum of the market value of equity, long term and short term debt scaled by total assets; Growth is the percentage change in total assets from year $\mathrm{t}-2$ to $\mathrm{t}-1$, when Investment is measured in t; Age is the natural logarithm of the difference between the first year the firm enters Compustat and the current year. MVE is the natural logarithm of

\footnotetext{
${ }^{16}$ My inferences are unchanged when I use the sum of capital and $R \& D$ expenditure as a measure of investment. Richardson (2006) uses a measure of investment that includes acquisitions in addition to capital expenditure and R\&D. I do not examine acquisitions because they have an ambiguous effect on financial covenants. Further, information generated within the company is relatively less important for acquisitions because of the larger role played by the quality of the targets' accounting practices and valuation.
} 
market value of equity; $\mathrm{CFO}$ represents the cash flows from operations reported in the statement of cash flow; Cash is cash and cash equivalents; Leverage is the sum of short- and long-term debt, and Returns is stock returns from year t-1 to year t. I deflate Investment, CFO, Cash, Leverage, and Cumulative Effect by the average of assets in period $\mathrm{t}$ and $\mathrm{t}-1$. See Appendix B for variable definitions.

The variables Tobin's Q, Growth, and Age are used to proxy for available investment opportunities (Adam and Goyal, 2008; McNichols and Stubben, 2008; Richardson, 2006). $\mathrm{CFO}$, Cash, and Leverage proxy for financing constraints and agency problems associated with free cash flows, while MVE is a proxy for both investment opportunities and the availability of financing (McNichols and Stubben, 2008; Richardson, 2006). I also control for contemporaneous Returns to account for any changes in risk (Richardson, 2006). I control for lagged Investment, which gives the regression coefficients a changes interpretation and captures a firm-specific component to investment decisions not captured by the other variables (McNichols and Stubben, 2008). Lastly, I include indicator variables for each two-digit SIC industry or for each change in GAAP in my regressions (Jackson et al., 2009; Biddle et al., 2009). The indicator variables filter out industry- or standard-specific patterns in investment.

\subsection{Measuring Changes in Investment Efficiency}

I measure investment efficiency as the magnitude of the deviation of actual investment from the expected level of investment given the firm's investment opportunities 
using two models of expected investment extensively given in prior studies. The two models of expected investment are as follows:

$$
\begin{aligned}
& \text { Investment }_{i, t}=\beta_{0}+\beta_{1} \text { Sales Growth }_{i, t-1}+e_{i, t} \\
& \text { Investment }_{i, t}=\gamma_{0}+\gamma_{1} \text { Tobin's }_{i, t-1}+\gamma_{2} \mathrm{CFO}_{i, t}+r_{i, t}
\end{aligned}
$$

where Investment is defined as either capital expenditure or the sum of capital and $R \& D$ expenditure. ${ }^{17}$ Sales Growth is the percentage changes in sales from year $\mathrm{t}-2$ to $\mathrm{t}-1$; Tobin's $Q$ and CFO are as defined earlier. Equations (1) and (2) are estimated using all firms in Compustat for each industry-year based on the Fama-French 30 industry classification for all industries with at least 20 observations each year. The magnitudes of the residuals from each model (multiplied by minus one) are my primary measures of investment efficiency. ${ }^{18}$ Examples of prior studies that use one of the above models to measure expected investment are as follows. The first model is used by Wurgler (2000), Whited (2006), Acharya et al. (2007), and Biddle et al. (2009). The second model of expected investment is used by Fazzari et al. (1988), Hoshi et al. (1991), Biddle and Hillary (2006), and McNichols and Stubben (2008).

\footnotetext{
${ }^{17}$ For the investment efficiency regressions I do not measure investment using $R \& D$ expenditure alone because more than half my sample firms do not invests in $R \& D$, which makes the OLS estimator unsuitable to estimate equations (1) and (2). Further, the residuals from alternative models that allow the dependent variable to have a mass point (e.g., Tobit model) do not lend themselves to measuring investment efficiency since the residuals are not orthogonal to the independent variables. To overcome this issue, I use the sum of capital and $R \& D$ expenditure as an alternative measure of investment.

${ }^{18}$ I examine the robustness of my inferences to two additional measures of investment efficiency using alternative models for expected investment. First, I use a modified version of Equation (2) that includes lagged growth, lagged investment, and allows for variation in the relation between investment and Tobin's $Q$ across different quartiles of Q (McNichols and Stubben, 2008; pg. 1579); and second, I use all the determinants of investment stated in section 3.1 to measure expected investment. I find that my inferences are unchanged with these alternative models of expected investment.
} 


\subsection{Identifying Changes in GAAP}

The FASB allows firms flexibility in the timing and method of adoption of new accounting standards. ${ }^{19}$ Therefore, the year in which a change in GAAP is made mandatory cannot be used to identify firms that change accounting rules. Further, even though the adoption of changes in GAAP is mandatory for all publicly traded firms, there is significant cross-sectional variation in the impact each accounting standard has on adopting firms' financial statements and in the impact different standards have on firms' financial statements (i.e., both within and between standard variation in impact).

To overcome problems identifying when firms adopted an accounting change and to exploit variation in the impact an accounting change had on firms' financial statements, I use the Cumulative Effect of an accounting change (scaled by average assets) to identify and to measure the magnitude and sign of the impact a change in GAAP has on firms' financial statements. The cumulative effect is a one-time, non-cash, below-the-line item reflecting the prior-period or 'catch-up' effect of changing an accounting practice, which is recognized in the current period's income statement. This amount captures the difference between the old and new accounting rules, and the extent to which each firm used the transaction (or economic activity) for which the accounting changed. Computationally, the

\footnotetext{
${ }^{19}$ Accounting rule changes can be adopted using a combination of four methods: prospective, retroactive, catch-up, and retroactive/catch-up (Balsam et al., 1995). Under the prospective method, the accounting change is adopted prospectively and it affects only current and future periods' financial results. The retroactive method requires that all prior years' financial statements presented as comparative income statements/balance sheets be restated to reflect the accounting change (to the extent such computation is possible). Under the catch-up approach, the prior-period effects of changes in GAAP are recognized as the "cumulative effect of an accounting change" in the current period's income statement. Lastly, the retroactive/catch-up approach requires firms to include the cumulative effect of an accounting change in the earliest year's comparative income statement presented along with the current period's income statement. Under Accounting Principles Board Opinion No. 20 - the accounting rule governing changes in GAAP prior to 2005 - most accounting changes were implemented using the catch-up method. For fiscal years beginning after December 15, 2005, SFAS 154 governs the accounting for transition adjustments due to changes to GAAP and it requires firms to primarily use the retroactive method.
} 
cumulative effect of an accounting change is the difference between the owner's equity under the old accounting rules, and the owner's equity after the change in GAAP.

Although using the cumulative effect of an accounting change allows me to identify firms that adopted a new accounting standard and to exploit cross-sectional variation in the impact of accounting changes on firms' financial statements, there are two limitations of the measure: 1) not all changes in GAAP require firms to use the catch-up method to account for the transition to the new GAAP, and 2) firms often have some choice in the method and timing of adopting changes in GAAP. The first limitation limits the number of rule changes in the sample but is unlikely to create any systematic bias in my inferences. However, the second limitation warrants discussion, which I do in detail in section 6 .

\subsection{Measuring the Likelihood that a Change in GAAP Informs Managers}

I exploit differences in the characteristics of the new accounting pronouncement to classify change in GAAP into two groups, Information and No Information, based on their likelihood of providing managers with decision-facilitating information. To classify standards, I read all the standards in my sample and evaluate the likelihood that they provide managers with information along the following dimensions. One, I examine whether the change in GAAP increased the amount and complexity of accrual accounting estimates that managers are required to make. Managers require information to estimate the numbers reported in public financial statements, some of which may not be readily available. Therefore, standards that increase estimation requirements are more likely to provide managers with information. Two, standards that may require firms to hire outside 
experts such as actuaries and appraisers to aid with compliance are classified as more likely to inform managers (e.g., Goodwill - SFAS 106, Asset Retirement Obligation - SFAS 143). Finally, I examine whether the stated objective of the new standard is to make financial statements more relevant for valuation. Although FASB strives to make financial statements both relevant and reliable, there is generally a trade off between the two objectives. Therefore, some standards (e.g., SAB 101 - Revenue Recognition) are designed to make financial statements more reliable whereas other standards (e.g., SFAS 142 Goodwill) are designed with the objective improving financial statement relevance. Standards designed to improve relevance are more likely to inform managers since relevant information by definition should help predict future cash flows. Table 2 and Appendix A contain my classification scheme and a detailed discussion of my classification choices for the major standards in my sample.

To validate my classification, I examine whether the Cumulative Effects arising from standards classified as more likely to inform managers are more closely associated with concurrent stock returns than the Cumulative Effects arising from standards classified as less likely to inform managers, controlling for contemporaneous earnings. Assuming managers' information sets are fully impounded in stock prices, we would observe an association between stock returns and the Cumulative Effect - a one time catch up effect of the accounting change - only if the Cumulative Effect provides managers with new information. I find that the Cumulative Effects arising from standards identified as more likely to inform managers have a significantly stronger association with stock returns than standards less likely to inform managers (unreported), thereby at least partially validating my 
classification. I also conduct sensitivity tests to ensure the robustness of my results to this classification scheme (Chapter 7).

\subsection{Measuring Debt Contracting Incentives}

Debt covenants are generally tailored for each contract and exhibit significant differences in their computation across contracts. Such heterogeneity in covenant definitions makes it very costly to accurately compute covenant slack for a large sample of observations. Therefore, I measure debt contracting incentives using the presence of a debt covenant in firms' private debt agreements. Since covenants in private debt contracts are tightly set (Kahan and Tuckman, 1993; Dichev and Skinner, 2002) the presence of a covenant is likely to be a reasonable proxy for covenant slack while filtering out some of the measurement error likely to be present in any measure of slack.

Specific to my research question, I note that debt contracts include several covenants, not all of which are affected by the Cumulative Effect. For example, a covenant limiting the maximum debt to cash flows ratio will be unaffected by the Cumulative Effect since the Cumulative Effect does not have any direct cash flow implication. Further, debt contracts differ with respect to how they deal with changes in GAAP. Prior research identifies three common debt contracting practices: the "fixed" GAAP practice that excludes all accounting changes once the contract is signed; the "floating" GAAP practice that uses the most upto-date GAAP; and a hybrid that gives lenders and borrowers a "mutual option to freeze"

GAAP at any point in time (see Mohrman, 1996; Beatty et al., 2002; Christensen and Nikolev, 2009). The covenant slack in debt contracts that use the fixed or hybrid GAAP 
are unaffected by changes in GAAP because they explicitly disallow (or provide contracting parties the option to disallow) such changes to covenants. Therefore, only covenants in floating GAAP debt contracts are likely to create managerial incentives to change investment behavior. To incorporate this institutional feature of debt contracts in my tests, I construct two indicator variables - Covenant and Floating GAAP - that take on the value of one if the firm-year has at least one covenant that can be affected by the Cumulative Effect, and if the debt agreement uses the floating GAAP practice, respectively. ${ }^{20}$

\footnotetext{
${ }^{20}$ From reading contractual provisions I find that some debt agreements allow contracting parties to renegotiate covenant thresholds after a change in GAAP and require firms to reconcile and disclose any change in financial ratios due to the change in GAAP. Such disclosures might affect the outcome of negotiations relating to covenants in the loan agreement and hence, might affect firm behavior as well. Therefore, I refer to both, covenants in agreements with floating GAAP and agreements requiring reconciliation disclosures as Floating GAAP.
} 


\section{CHAPTER 4}

\section{Data and Sample Selection}

I begin my sample construction by identifying firm-years in the intersection of CRSP and Compustat with non-missing and non-zero values for the Cumulative Effect of an accounting change. However, both voluntary and mandatory accounting changes can cause firms to book a Cumulative Effect, and including voluntary accounting change in my sample raises endogeneity concerns. ${ }^{21}$ To eliminate voluntary accounting changes from my sample, I hand collect information from $10 \mathrm{~K}$ filings for the subset of observations in Compustat that have a non-missing and non-zero Cumulative Effect. The information in $10 \mathrm{~K}$ filings helps me decipher not only whether the accounting change is mandatory or voluntary but also which mandatory accounting change caused firms to book a Cumulative Effect. Requiring electronic 10K filings from Edgar constrains my sample to begin in 1991.

The above criteria yield 5,530 firm-year observations between 1991 and 2007. Requiring data to compute average assets reduces my sample to 5,241 observations. I drop firms operating in any regulated industry and the financial industry since their incentives differs from that of industrial firms, and they often have regulatory restrictions on investment. Further, these firms also have accounting-based regulatory requirements (e.g.,

${ }^{21}$ For example, Sweeney (1994) shows that managers of firms approaching default adopt income increasing voluntary accounting changes prior to violating covenants. To the extent firms approaching covenant violations also encounter a decline in investment opportunities, including voluntary accounting changes in my sample could be problematic. 
rate-regulation, regulatory capital, etc.), which affect their accounting choices (Beatty, 2007). Explicitly modeling these incentives is beyond the scope of this paper, and hence I drop these firms, leaving 3,903 observations. ${ }^{22}$ Data requirements for other independent variables further reduce my sample to 3,473 observations. Missing $10 \mathrm{~K}$ filings and $10 \mathrm{~K}$ filings with insufficient information about the cumulative effect of an accounting change reduce my sample to 3,012 observations, of which 2,795 observations have mandatory accounting changes and 217 observations have voluntary accounting changes. My final sample comprises 2,795 firm-years, 2,033 unique firms, and forty-nine changes in GAAP from 1991 to 2007 (see Table 4.1).

I also require data on the presence of financial covenants to test my fourth hypothesis, which I obtain from Loan Pricing Corporation's Dealscan database. Dealscan contains data on loan agreements for $59 \%$ of my sample. I assume that observations not in Dealscan do not have private debt agreements. ${ }^{23}$ Lastly, I hand collect data on the contracting practices - Fixed, Floating, or Mixed GAAP - used in the loan agreements of my sample firms. I obtain loan agreements for 371 of the 652 observations in my sample with relevant covenants from either Amir Sufi's website or Edgar, and I identify the contracting practice used in these agreements. ${ }^{24}$ I conduct all analysis requiring data on the definition of GAAP

\footnotetext{
${ }^{22}$ However, I find that my inferences are unchanged when I keep firms in financial or regulated industries in my sample.

${ }^{23}$ The Dealscan database contains between $50 \%$ and $75 \%$ of the value of all commercial loans in the U.S. during the early 1990s (Carey and Hrycray, 1999). From 1995 onward, Dealscan coverage increases to include an even greater fraction of commercial loans (Chava and Roberts, 2008). Therefore, assuming that only the firms covered by Dealscan have private debt agreements is unlikely to cause much measurement error.

${ }^{24}$ Firms are required by the SEC to file material contracts with the SEC and Nini et al. (2009) obtain a sample of 3,720 contracts by electronically searching through SEC filings for certain terms that are common to private credit agreements. This data are available on Amir Sufi's website (http://faculty.chicagobooth.edu/amir.sufi/data.htm). For the most part, I obtain loan agreements from Amir Sufi's website but I augment their data by obtaining some on my own.
} 
used in loan agreements using this smaller sample of 2,514 observations, i.e., 371

observations with covenants and identified GAAP definitions in contracts, and 2,143

observations without covenants that are affected by the Cumulative Effect. 


\section{CHAPTER 5}

\section{Research Design and Empirical Analyses}

\subsection{Summary Statistics and Correlations}

Table 5.1 reports descriptive statistics of the changes in GAAP in my sample. Table 5.1, Panel A shows the major accounting changes in my sample along with the years of adoption, methods of implementing the standard, the mean Cumulative Effect for the rule change, the number of observations for each standard, and whether the standard is classified as likely to provide managers with information. The table shows that there is considerable variation in the average Cumulative Effect across the standards. Further, all the standards allow some discretion with respect to the year in which a standard can be adopted. Table 5.1, Panel B shows the number of observations and the accounting standards adopted each year along with the scaled and unscaled mean Cumulative Effect.

Table 5.2 reports the summary statistics for variables used in the regression analysis. The mean (median) Cumulative Effect is $-2.6 \%(-0.3 \%)$ of average total assets suggesting that accounting rule changes can have economically significant impacts on bottom line earnings and book equity. The mean RED Expenditure is 0.033 while the median is zero, indicating that more than half of the firm-year observations in my sample do not invest in $R \& D$. The average firm in my sample is 21 years old, has a market value of equity of $\$ 3.3$ billion, and cash flows from operations amounting to $6.7 \%$ of average assets. These 
statistics indicate that the average firm in my sample is large and profitable. However, the other statistics in the table show that there is considerable variation in size and profitability of firms in my sample. Table 5.2 also shows that $66.8 \%$ of the observations in my sample adopted accounting standards that are likely to inform managers; $58.7 \%$ of the observations are covered by the Dealscan database, and $23.3 \%$ of the observations have financial covenants in their loan agreements that are likely to be affected by the Cumulative Effect. Further, the table shows that of the 371 observations for which I find loan agreements, $43.9 \%, 35.8 \%$ and $20.2 \%$ follow fixed, hybrid, and floating GAAP, respectively, which is similar to that documented by Christensen and Nikolaev (2009).

Table 5.3 presents the Pearson correlation coefficients and $\mathrm{p}$-values for the variables used in the regression analysis. The univariate correlations indicate a positive relation between Capital Expenditure and the Cumulative Effect, consistent with H1, but a negative relation between RED Expenditure and the Cumulative Effect. Surprisingly, the Cumulative Effect is also correlated with the other control variables listed in the table. Upon further investigation I find that these correlations are largely due to strong calendar year effects present in the Cumulative Effect. Once I account for calendar effects by clustering standard errors by year, the correlations between the Cumulative Effect and Tobin's Q, Growth, Ln(Age), Ln(MVE), and Cash $\mathcal{E}$ Marketable Securities becomes statistically insignificant while the correlation between the Cumulative Effect and Capital Expenditure remains statistically significant. The table also shows that Tobin's Q, Growth, and Ln(Age) - proxies for investment opportunities - are correlated with both measures of investment in the expected direction. Further, CFO and Capital Expenditures are positively correlated, 
consistent with the 'investment-cash flow sensitivity' literature (see Fazzari et al., 1988). Consistent with Biddle et al. (2009), I find that $\Delta$ Financial Reporting Quality - minus one times the change in the Dechow and Dichev (2002) measure of accounting quality - is positively related to all four measure of investment efficiency. However, the correlation between $\Delta$ Financial Reporting Quality and Cumulative Effect (both signed and unsigned) are insignificant suggesting that changes in GAAP do not affect accounting quality on average.

\subsection{Regression Analysis - Test of $\mathrm{H} 1$}

To examine the relation between changes in GAAP and managerial investment, I test whether the Cumulative Effect of an accounting change is associated with capital and R\&D investment after controlling for the determinants of investment documented in prior research. Specifically, I estimate the following regression (see Section 3.1 or Appendix B for variable definitions).

$$
\begin{aligned}
& \beta_{0}+\beta_{1} \text { Cumulative Effect }_{i, t}+\beta_{2} \text { Investment }_{i, t-1}+\beta_{3} \text { Tobin's }_{\text {( }} \text { Q }_{i, t-1} \\
\text { Investment }_{i, t}= & +\beta_{4} \text { CFO }_{i, t}+\beta_{5} \text { Growth }_{i, t-1}+\beta_{6} \text { Age }_{i, t}+\beta_{7} \mathrm{MVE}_{i, t}+\beta_{8} \text { Cash }_{i, t-1}+ \\
& \beta_{9} \text { Leverage }_{i, t}+\beta_{10} \text { Returns }_{i, t-1}+\text { Industry Indicators }+\varepsilon_{i, t}
\end{aligned}
$$

The coefficient of interest in equation (3) is $\beta_{1}$, which captures the relation between changes in GAAP and Investment. When Capital Expenditure is the type of investment, I estimate equation (3) using ordinary least squares (OLS), and I compute standard errors that are robust to the presence of time-series and cross-sectional correlation in the residuals by clustering them at the firm and year level (Petersen, 2009; Gow et al., 2010). This method accounts for residual correlation due to period specific shocks to investment and serial correlation in investment within a firm. When REDD Expenditure is the type of 
investment, I estimate equation (3) using the Tobit model (Tobin, 1958). Since RED Expenditure is zero for a substantial part of my sample but positive for the rest of the sample, OLS estimates of the regression coefficients are inconsistent (see Wooldridge, 2002; pg. 524). ${ }^{25,26}$ I examine the contemporaneous relation between Investment and the Cumulative Effect to mitigate concerns that the relation between investment and changes in GAAP is due to the information obtained from the financial statements of other firms (e.g., Durnev and Mangen, 2009) or due to feedback effects where financial information reported to capital markets affects capital market pricing of the firm, which in turn affects firms' real decisions (Kanodia, 2007; Plantin et al., 2008; Sapra, 2010; Bhat et al., 2010). However, I find that my results are robust using future Investment as the dependent variable.

Table 5 reports the results from estimating equation (3). I find that the coefficient for the Cumulative Effect is positive and statistically significant at the $1 \%$ level both when the dependent variable is Capital Expenditure and when it is RED Expenditure. The coefficients suggest that changes in accounting standards affect investment in both physical and knowledge capital, consistent with my hypotheses. In terms of economic magnitude, I find

\footnotetext{
${ }^{25}$ There is little dispute that OLS estimates are inconsistent for modeling R\&D expenditures because of the mass point at zero. However, since R\&D expenditure is not "censored" at zero but rather firms choose to invest nothing in $R \& D$, some papers advise against using the Tobit model (e.g., Maddala, 1991) while other econometrics texts suggest the opposite (e.g., Wooldridge, 2002; Greene, 2003). I discuss the robustness of my results to other estimation techniques in Section 7.

${ }^{26}$ For regressions with $R \& D$ as the dependent variable, I cluster standard errors only by year. I find that when implementing two-way clustering of standard errors for the $R \& D$ regressions, the estimated variance matrix has negative elements on the diagonal of the matrix, indicating a negative variance for some of the covariates in the regression. Since two-way clustering is basically standard errors clustered along each dimension (i.e., firm and year in my case) minus the standard errors clustered along the intersection of the two dimensions, large enough estimates of the standard errors clustered along the intersection can lead to negative standard error estimates based on two-way clustering. Cameron, Gelbach, and Miller (2010) suggest that this problem primarily occurs when there is "actually no need to cluster in more than one dimension."
} 
that a one standard deviation increase in the Cumulative Effect leads to a 3.38 percentage point increase in Capital Expenditure from its mean, ceteris paribus. To get a sense of the importance of accounting changes I compare the economic magnitude of the Cumulative Effect with that of CFO. I find that a one standard deviation increase in CFO leads to a 5.06 percentage point increase in Capital Expenditure suggesting that the impact of accounting changes on investment is approximately $67 \%$ as large as that of cash flows from operations in the year of the accounting change. The control variables generally line up consistent with expectations and prior research. Specifically, Tobin's Q, Growth, Returns, and lagged Investment are positively associated with current Investment. CFO is positively related to Capital Expenditure (consistent with the investment-cash-flow-sensitivity literature), and negatively related to $R \mathcal{E} D$ Expenditure (due to $R \& D$ expensing).

To corroborate my findings, I also estimate regressions where I replace the industry indictors with 23 indicator variables, one for each accounting standard group reported in Table 2. The benefit of including fixed effects for accounting standards is that the idiosyncratic attributes of individual accounting rules are filtered out in the estimation. Idiosyncratic attributes might cause some accounting standards to have systematically larger Cumulative Effects than others, or to have Cumulative Effects more subject to managerial discretion than others. ${ }^{27}$ Including accounting standard fixed effects removes idiosyncratic features of a standard, and the coefficient for Cumulative Effects in the regression captures only the common effect of all accounting changes on investment decisions. However, the drawback of including accounting standard fixed effects is that some information relevant

\footnotetext{
${ }^{27}$ For example, some accounting standards allow more discretion in the method of adopting the standard than others (such as SFAS 106 vs. SAB 101) or some standards might allow more discretion in estimating the magnitude of the Cumulative Effect (e.g., SFAS 142 vs. SAB 101).
} 
for documenting a relation between accounting changes and investment will also get filtered out in the process.

Table 5 shows that the coefficient for the Cumulative Effect in both the Capital Expenditure and RED Expenditure regressions continues to be positive and statistically significant at the $1 \%$ level or better, but it drops in magnitude from $0.044(0.016)$ to 0.017 (0.013) in the Capital Expenditure (RED Expenditure) regression. This is to be expected given that only a subset of the variation in the Cumulative Effect is used to estimate the relation between the accounting changes and investment decisions.

\subsection{Regression Analysis - Tests of $\mathrm{H} 2 a, \mathrm{H} 2 b$, and $\mathrm{H} 3$}

Part A of my second hypothesis suggests that changes in accounting rules affect investment decisions by informing managers about the NPV of their investments. To test this hypothesis, I augment equation (3) by including additional independent variables to capture the relation between the Cumulative Effect and Investment conditional on the change in GAAP providing managers with information to facilitate their investment decisions.

$$
\text { Investment }_{i, t}=\begin{aligned}
& \beta_{0}+\beta_{1} \text { Information } \times \text { Cumulative Effect }_{i, t}+\beta_{2} \text { No Information } \times \\
& \text { Cumulative Effect } \\
& \text { Cut, }_{i, t}+\beta_{3} \text { Information }_{i, t}+\sum \lambda^{\prime} \text { CONTROLS }+\varepsilon_{i, t}
\end{aligned}
$$

Information (No Information) is an indicator variable that takes on the value of one if a firm adopts a standard that is likely (unlikely) to provide managers with decision facilitating information; the variable equals zero otherwise. CONTROLS is a vector of control variables listed in equation (3) and described in Section 3.1. The coefficient of interest is $\beta_{1}$, which captures the relation between changes in GAAP and Investment when firms adopt standards 
likely to inform managers about the NPV of their investments or available opportunities. ${ }^{28}$

$\mathrm{H} 2 \mathrm{a}$ predicts that $\beta_{1}$ will be greater than zero. Table 6 presents the results from estimating equation (4). The table shows that the coefficient for the interaction term between Information and Cumulative Effect is positive and statistically significant at the $1 \%$ level for both Capital and REDD Expenditure decisions. The coefficient suggests that accounting changes affect investment decisions when compliance with the standard provides managers with decision facilitating information, consistent with $\mathrm{H} 2 \mathrm{a}^{29}$

The contracting hypothesis suggests that the relation between the cumulative effect and all changes in GAAP that alter contracting outcomes should be positive. However, Table 6 shows that the coefficient for the interaction term between No Information and Cumulative Effect $(\beta 2)$ is statistically insignificant for both Capital and REDD Expenditure. This result suggests that managers, on average, do not change long-term investment behavior to affect contracting outcomes due to changes in GAAP when information effects are not present. I investigate this further in the next section.

Part B of my second hypothesis predicts that if changes in accounting rules facilitate managerial investment decisions then the changes in accounting rules should improve managerial investment decisions as well. Further, any improvement in managerial investment decisions will be greater for diversified firms that have more complex

\footnotetext{
${ }^{28}$ I note that interaction terms in non-linear models such as Tobit do not equal the marginal effect of the interaction term (Ai and Norton, 2003). However, since my interest is in the relation between the Cumulative Effect and Investment conditional on Information equaling one (rather than the incremental effect of Information), the usual marginal effects apply.

${ }^{29}$ I do not control for accounting standard fixed effects because the differences in accounting standards helps me classify them as more or less likely to inform managers and identify the information hypothesis. However, I find statistically similar but economically weaker results when I replace industry fixed effects with accounting standard fixed effects (unreported).
} 
information environments within the firm $(\mathrm{H} 3)$. I test these hypotheses by estimating the following regressions.

$$
\begin{aligned}
& \beta_{0}+\beta_{1} \text { Information } \times \text { Unsigned Cumulative } \text { Effect }_{i, t}+ \\
& \begin{aligned}
\Delta \text { Investment Efficiency }_{i, t+1}= & \begin{array}{l}
\beta_{2} \text { No Information } \times \text { Unsigned Cumulative Effect }_{i, t}+ \\
\beta_{3} \text { Information }_{i, t}+\beta_{4} \Delta \text { Financial Reporting Quality } \\
\text { Int }_{t+1}
\end{array}+
\end{aligned} \\
& \beta_{5} \Delta \text { Number of Analysts }{ }_{i, t}+\beta_{6} \text { Anstitutional Ownership }{ }_{i, t}+\varepsilon_{i, t} \\
& \beta_{0}+\beta_{1} \text { Unsigned Cumulative Effect }_{i, t}+\beta_{2} \text { Organizational } \\
& \Delta \text { Investment Efficiency }_{i, t+1}=\begin{array}{l}
\text { Complexity } \times \text { Unsigned Cumulative Effect }_{i, t}+\beta_{3} \text { Organizational }_{\text {Complexity }}+\beta_{4, t} \Delta \text { Financial Reporting } \text { Quality }_{i, t+1}+\beta_{5} \Delta \text { Number }
\end{array} \\
& \text { of Analysts } \text { i,t }+\beta_{6} \Delta \text { Institutional Ownership }_{i, t}+\varepsilon_{i, t}
\end{aligned}
$$

$\Delta$ Investment Efficiency is the change in investment efficiency from the year $t-1$ to $t+1$; the accounting change is adopted in year $t$. The above tests require a measure of the magnitude of the impact a change in GAAP has on the firm's financial statements. Therefore, I use the absolute value of the Cumulative Effect in the above regressions. $\triangle$ Financial Reporting Quality is minus one times the change in the Dechow and Dichev (2002) measure of accounting quality with the modification suggested by McNichols (2002), from the year t-1 to $t^{+}+.^{30} \Delta$ Number of Analysts and $\Delta$ Institutional Ownership are the change in the number of analysts following the firm, and the proportion of the firm's stock held by institutional investors from the year $\mathrm{t}-1$ to $\mathrm{t}$, respectively. Organizational Complexity is measured using a Herfindahl index for business segment diversification (Bushman et al., 2004). I also include industry fixed effects using indicator variables for each 2-digit SIC code in the above regressions.

\footnotetext{
${ }^{30}$ I measure the change in investment efficiency and financial reporting quality as the difference between the respective measures in year $t+1$ and $t-1$, where the change in GAAP was adopted in year $t$. Since the measures of investment efficiency (financial reporting quality) are computed using lagged values of investment opportunities (cash flows), I do not measure these variables in the year of the accounting change to avoid measuring the dependent and independent variables under different sets of GAAP.
} 
Biddle and Hillary (2006) and Biddle et al. (2009) show that firms with better reporting quality invest more efficiently. Since changes in GAAP might also change firms' financial reporting quality, I control for concurrent changes in reporting quality. I also control for changes in corporate governance and external monitoring around the change in GAAP using the change in the number of analysts following the firm, and the proportion of the firm owned by institutional investors to address the possibility that firms with strong corporate governance structures and external monitoring mechanisms are less likely to under- or over- invest (Biddle et al., 2009).

The coefficient of interest in equation (5) is $\beta_{1}$ and it captures the relation between the quality of managerial investment decisions and the magnitude of the impact a change in GAAP has on a firm's financial statements when the change in GAAP is likely to inform managers. $\mathrm{H} 2 \mathrm{~b}$ predicts that $\beta_{1}$ will be positive. Table 7 shows that changes in GAAP that are likely to inform managers lead to an improvement in investment efficiency, consistent with H2b. Specifically, I find that the coefficient for the interaction between Information and Unsigned Cumulative Effect is positive and statistically significant at the $10 \%$ level or better in all four regressions. In terms of economic significance, I find that a one standard deviation increase in Unsigned Cumulative Effect (4 Financial Reporting Quality) leads to a 14 (21) percentage point increase in the change in investment efficiency from its mean, ceteris paribus.

The coefficients of interest in equation (6) are $\beta_{1}$ and $\beta_{2}$. $\beta_{1}$ captures the relation between the quality of managerial investment decisions and the magnitude of the impact a change in GAAP has on a firm's financial statements, and $\beta_{2}$ captures the incremental 
effect of this relation for firms with complex information environments. $\mathrm{H} 2 \mathrm{~b}$ predicts that $\beta_{1}$ will be positive, and $\mathrm{H} 3$ predicts that $\beta_{2}$ will be positive. Consistent with $\mathrm{H} 2 \mathrm{~b}$, I find that the coefficient for the Unsigned Cumulative Effect is positive and statistically significant at the $5 \%$ level or better in all four regressions; and consistent with $\mathrm{H} 3$, I find that the coefficient for the interaction between the Unsigned Cumulative Effect and Organizational Complexity is also positive and statistically significant at the $5 \%$ level or better in three of the four regressions (see Table 8). The results suggest that changes in GAAP improve managerial investment efficiency and that the improvement in investment efficiency is greater for firms with complex internal information environments. Interestingly, Tables 7 and 8 also show that the coefficient for $\Delta$ Financial Reporting Quality is positive and generally statistically significant. This result is consistent with the findings in McNichols and Stubben (2008) and Biddle et al. (2009) who document a relation between financial reporting quality and investment efficiency. My results support their findings in a different setting using changes in investment efficiency and changes in reporting quality due to changes in GAAP. Also consistent with Biddle et al. (2009), I find that the coefficients for $\Delta$ Number of Analysts and $\Delta$ Institutional Ownership are statistically insignificant across all specifications. Collectively, the results in Tables 6,7 , and 8 provide robust evidence that changes in GAAP affect and improve managerial investment decisions by providing them with decision facilitating information. 
5.4 Regression Analysis - Tests of $\mathrm{H} 4$

My final hypothesis predicts that changes in GAAP are likely to affect managerial investment when firms have financial covenants that are affected by the Cumulative Effect. To test this prediction, I augment equation (3) by including additional covariates to capture the relation between the Cumulative Effect and Investment conditional on the presence of a Covenant and the definition of GAAP used in the lending agreement (i.e., floating GAAP vs. others).

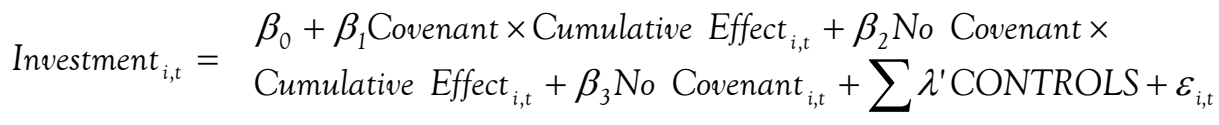

$$
\begin{aligned}
& \beta_{0}+\beta_{1} \text { Covenant } \times \text { Floating GAAP } \times \text { Cumulative Effect }{ }_{i, t}+\beta_{2} \text { Covenant } \times \\
& \begin{array}{l}
\text { Investment }_{i, t}=\begin{array}{l}
\text { No Floating GAAP } \times \text { Cumulative Effect } \\
i, t
\end{array}+\beta_{3} \text { No Covenant }_{i, t} \times \text { Cumulative } \text { Effect }_{i, t}+\beta_{4} \text { No Covenant }+\beta_{5} \text { Covenant } \times \text { Floating GAAP }_{i, t}+
\end{array} \\
& \sum \lambda^{\prime} \mathrm{CONTROLS}+\varepsilon_{i, t}
\end{aligned}
$$

Covenant is an indicator variable that takes on the value of one if the firm-year has at least one covenant that can be affected by the Cumulative Effect. No Covenant is an indicator variable that takes on the value of one (zero) if Covenant equals zero (one). Floating GAAP is an indicator variable that takes on the value of one if the debt agreement uses the floating GAAP practice or requires the firm to disclose reconciliations between the old and new accounting practice while renegotiating covenants to adjust for the change in GAAP. No Floating GAAP is an indicator variable that takes on the value of one (zero) if Floating GAAP equals zero (one). CONTROLS is a vector of control variables listed in equation (3) and described in Section 3.1. The coefficient of interest in equation (7) is $\beta_{1}$, which captures the relation between changes in GAAP and Investment for firms with Covenants. However, as discussed previously, some loan agreements explicitly provide for a course of action in 
the event of a change in GAAP, and hence are less likely to be affected by changes in GAAP. Therefore, I decompose the interaction between Covenant and Cumulative Effect into two variables in equation (8), the first capturing the interaction between Floating GAAP and Cumulative Effect $\left(\beta_{1}\right)$, and the second capturing the interaction between No Floating GAAP and Cumulative Effect $\left(\beta_{2}\right)$. The coefficients of interest in equation (8) are $\beta_{1}$ and $\beta_{2}$, which capture the relations between changes in GAAP and Investment for firms with Covenants and Floating GAAP loan agreements, and Covenants and No Floating GAAP loan agreements, respectively.

Table 9 reports the results from estimating equations (7) and (8). Panel A in Table 9 shows that the coefficient for the interaction term between Covenant and Cumulative Effect is positive and statistically significant at the 1\% level for both the Capital Expenditure and RED Expenditure regressions. These results indicate that changes in GAAP have a significant impact on investment decisions in the presence of financial covenants. Table 9 , Panel A also shows that the coefficient for the interaction between Floating GAAP and Cumulative Effect is positive and statistically significant at the $1 \%$ level while the coefficient for the interaction between No Floating GAAP and Cumulative Effect is statistically insignificant in the RED Expenditure regression. ${ }^{31}$ Together these results suggest that accounting changes have a significant impact on investment decisions in the presence of financial covenants and the effect is more pronounced when loan agreements do not contain explicit provisions for adjusting financial covenants after changes in GAAP.

\footnotetext{
${ }^{31}$ Although the coefficient for the interaction between No Floating GAAP and Cumulative Effect is statistically significant in the Capital Expenditure regression, it is smaller in magnitude than that for the interaction between Floating GAAP and Cumulative Effect (albeit insignificantly).
} 
To at least partially control for the information hypothesis, I re-estimate equations (7) and (8) after replacing the industry indicator variables with indicator variables for each accounting standard to control for their fixed effects. Columns (1) and (3) in Table 9, Panel B show that the coefficient for the interaction between Covenant and Cumulative Effect is statistically insignificant. However, I find that the coefficient for the interaction between Floating GAAP and Cumulative Effect is positive and statistically significant at the $1 \%$ level. These results suggest that changes in GAAP affect investment decisions in the presence of financial covenants only if loan agreements are based on Floating GAAP.

I also examine whether differences in the expected cost of renegotiating covenants affect the relation between changes in GAAP and investment for firms with covenants. Firms with declining performance are likely to find renegotiating the debt contract more costly because the decline in performance makes their debt less valuable. Hence, such firms are likely to have greater incentives to avoid covenant violation. On the other hand, firms whose performance has improved are likely to have more control while renegotiating debt contracts because the improvement in performance is likely to increase their bargaining power relative to the lenders. Consistent with the above prediction, I find that the relation between changes in GAAP and investment for firms with covenants (and floating GAAP contracts) is statistically significant only for firms whose earnings have declined (see Table 10). Specifically, for firms with negative (positive) earnings growth, the coefficient for the interaction between Floating GAAP and Cumulative Effect is 0.123 (0.028) in the Capital Expenditure regression; and in the RED Expenditure regression the corresponding coefficient for firms with negative (positive) earnings growth is 0.079 (0.009). Table 10 Panel B shows 
that the difference between firms with positive and negative earnings growth is even more pronounced when I replace industry fixed effects with accounting standard fixed effects. Collectively, these findings suggest that use of accounting numbers in contracts can cause changes in GAAP to affect managerial investment decisions, especially when firm performance declines around the change in GAAP. 


\section{CHAPTER 6}

\section{Identification and Endogeneity Concerns}

Firms often have some choice in the method and timing of adopting changes in GAAP, which could be correlated with their investment incentives leading to an endogeneity bias. A large literature on 'accounting choice' shows that contracting and market incentives influence managers' accounting choices including the method and timing of adoption of new standards (see Fields et al. (2001) for a review of the literature). Thus, when firms have a choice of whether to use the 'catch up' method to adopt new accounting rules, this choice could be correlated with managerial incentives to invest. Even when GAAP does not explicitly provide choice in the method of adopting new accounting rules, the cumulative effect of an accounting change could be affected by managerial discretion. I address this concern in the following ways. First, I control for accounting standard fixed effects in my statistical tests. Including fixed effects for changes in GAAP allows me to capture just the portion of the relation between accounting changes and investment decisions that is common to all changes in GAAP. Since managerial incentives and the discretion allowed by a change in GAAP vary for each new pronouncement, my inferences are less likely to be driven by un-modeled managerial incentives that are idiosyncratic to a standard when I control for accounting standard fixed effects. 
Second, I examine the robustness of my results to dropping firms that are early adopters of a standard, including year fixed effects, and an indicator variable for early adopters. To the extent incentives to adopt standards early are correlated with incentives to alter investment, my results could be biased. However, I find that my results are unaffected in all of the above tests. Note that the managerial incentives that drive accounting choices around changes in GAAP have to be correlated with the incentives that influence managerial investment decisions to affect my tests. For example, the incentives to report large positive cumulative effects need to be correlated with incentives to increase capital expenditure and $R \& D$ to affect my tests. To the extent this is unlikely, my inferences are unlikely to change due to any endogeneity bias.

Lastly, I examine whether the relation between the Cumulative Effect and both Capital and RED Expenditure is robust to using an instrumental variables approach (i.e., Two-Stage-Least-Squares) with the quintile rank of the Cumulative Effect serving as an instrument for the Cumulative Effect. This approach to create an instrument assumes that managers have limited discretion to manipulate the cumulative effect of an accounting change. Therefore, although the within quintile variation in the Cumulative Effect might be susceptible to managerial choice and thus endogenous, the between quintile variation in the Cumulative Effect is not subject to managerial choice (Hentschel and Kothari, 2001; Frankel et al., 2006). I find that my results are robust to using the instrumental variables approach.

Notwithstanding the above arguments, I also note that only five of the major changes in GAAP in my sample allowed choice in the method of adopting the standard, and in 
most cases, the managerial incentives at play are likely to bias my tests towards the null hypothesis of no relation between changes in GAAP and investment. For example, Beatty and Weber (2006) find evidence that contracting incentives created by the presence of debt covenants cause firms to postpone goodwill impairments rather than immediately book a below-the-line expense upon the adoption of SFAS 142 (Accounting for Goodwill). Further, they show that firms with covenants record smaller cumulative effects relative to firms without covenants. Their results suggest that firms with large negative (positive) cumulative effects are less (more) likely to have private debt covenants to begin with, which biases my tests towards the null of no relation between changes in GAAP and investment. However, to the extent the above arguments do not address endogeneity or other concerns, my results could be affected.

Another potential identification concern arises because accounting changes are endogenously determined by changes in the economic environment of the firm (Ball, 1980; Kothari et al., 2010). Therefore, an alternative hypothesis is that changes in GAAP are the outcome of, or occur simultaneously with changes in the firm's investment opportunities, which causes a change in investment. While such a hypothesis is plausible, I question its veracity for the following reason. For my inferences to be affected by such endogeneity the magnitude and sign of the impact an accounting change has on firms' financial statements would also have to be correlated with changes in firms' investing environments in the same direction. Further, this endogenous effect would have to persist across the many different accounting changes in my sample. However, prior research suggests that the factors leading up to each of these standards were significantly different from each other. For example, 
Ramanna (2008) shows that SFAS 142 was issued in response to political pressure over the abolition of pooling of interest accounting, Bens and Monahan (2008) suggest that FIN 46 was issued in response to the Enron Scandal, SAB 101 was issued over concerns that firms manipulate revenue recognition to manage earnings (Altamuro et al., 2005). Therefore, it is unlikely that the endogenous relation between changes in GAAP and firms' economic environments is the primary driver of my results. 


\section{CHAPTER 7}

\section{Additional Analyses and Robustness Checks}

\subsection{Simultaneously Testing both Information and Contracting Hypotheses}

To examine whether the relation between accounting changes and investment is dominated by any one of the mechanisms, I isolate the effect of each mechanism by decomposing the Cumulative Effect into four variables that capture different combinations of the two mechanisms. Specifically, I decompose the Cumulative Effect into the following groups by interacting it with indicator variables for the following: 1) firm-years with Covenants and Floating GAAP debt agreements adopting changes in GAAP with Information; 2) firm-years with Covenants and Floating GAAP debt agreements adopting changes in GAAP with No Information; 3) firm-years without any Covenants adopting changes in GAAP with Information; and 4) firm-years without any Covenants adopting changes in GAAP with No Information. Table 11 shows that the relation between changes in GAAP and Investment is restricted to those standards that are likely to inform managers suggesting that the information hypothesis is the primary reason for the relation between changes in GAAP and investment. The absence of evidence for the contracting hypothesis in this test suggests that the use of accounting numbers in contracts is not a major factor in determining managerial investment decisions for the average firm. Alternatively, it is plausible that decomposing the Cumulative Effect into four parts leads to a far too refined 
partitioning of the data, which results in this test having low power. My inferences are unchanged when I control for standard fixed effects rather than industry fixed effects in this test (unreported).

\subsection{The Tobit Model}

I examine the robustness of my tests concerning REBD Expenditure to using alternative estimation techniques besides the Tobit model. Investments in $R \& D$ are the outcome of economic choices made by firms, and for some firms the optimal choice will be the corner solution (i.e., RED Expenditure $=0$ ). When dealing with corner solution outcomes, some authors advise against using the Tobit model and recommend explicitly modeling the outcome (e.g., Maddala, 1991; pg. 796), while others consider the use of the Tobit model appropriate (e.g., Wooldridge, 2002; pg. 518). The former is based on the argument that the standard Tobit model assumes, among other things, that the dependent variable is censored at zero and can, in principle, take on negative values. Since RED Expenditure cannot take on negative values, Maddala's (1991) argument suggests that the use of the Tobit model is inappropriate. Wooldridge (2002) and Greene (2003), on the other hand, argue that the Tobit model lends itself to both situations - when the dependent variable is censored and when there are corner solutions. Therefore, I re-examine my hypotheses using two alternative specifications to the Tobit: 1) using OLS on the observations not at the mass point (i.e. where RED Expenditure >0 in my case) and 2) explicitly modeling the probability that REDD Expenditures is greater than zero and using a hurdle rate model (e.g., 
Cragg, 1971). ${ }^{32}$ I find that all hypotheses except $\mathrm{H} 4$ are robust to both specifications. The relation between changes in GAAP and REDD Expenditure conditional on having financial covenants is sensitive to specification choice. Further examination of the data reveals there are 1,281 observations with RED Expenditure greater than zero; of these, only 33 observations have financial covenants with floating GAAP. Therefore, the alternative tests are essentially relying on just 33 observations to identify the relation between changes in GAAP and investment. When I examine the relation between changes in GAAP and REDD Expenditure using just these 33 observations, I find that the coefficient for the Cumulative Effect is positive and has a one tailed p-value of 0.0625 . However, I note that my results for $\mathrm{H} 4$ are sensitive to the choice of estimation technique and suggest caution interpreting them.

Another criticism of the Tobit model is that it makes strong distributional assumptions (i.e., the error term is conditional normal and homoskedasticity). Therefore, I also estimate my results using the Conditional Least Absolute Deviation (CLAD) estimator (Powell, 1984). ${ }^{33}$ The CLAD estimator is a generalization of the Least Absolute Deviations estimator, which is robust to heteroskedasticity and makes fewer distributional assumptions. I find that my inferences are unchanged.

\footnotetext{
${ }^{32}$ I measure the probability of that RED Expenditures is greater than zero with an indicator variable for whether the firm invested in $R \& D$ in the previous year. I find that this model has high explanatory power due to the highly persistent nature of $R \& D$.

${ }^{33}$ The CLAD estimator is found by minimizing $\sum\left|y_{i}-\max \left(0, x_{i}^{\prime} \beta\right)\right|$.
} 


\subsection{Accounting Standards Classification}

I investigate whether my results for $\mathrm{H} 2 \mathrm{a}$ and $\mathrm{H} 2 \mathrm{~b}$ (i.e., do accounting changes affect and improve managerial investment decision by informing managers?) are sensitive to my classification of standards into groups. I drop one standard at a time from each group in my sample and re-run my tests for $\mathrm{H} 2 \mathrm{a}$ using the following regression specifications: 1) industry fixed effects, 2) standard fixed effects, 3) using ranks for the cumulative effect of an accounting change, and 4) using decile ranks for the cumulative effect of an accounting change. All in all I estimate 92 regressions with each dependent variable (i.e., capital and $R \& D$ expenditure). I find that in 90 (86) of the 92 regressions with capital (R\&D) expenditure as the dependent variable the coefficient for the Cumulative Effect is positive and statistically significant when the changes in GAAP are likely to inform managers (i.e., when Information equals one). For the investment efficiency regressions (i.e., tests of H2b), I again drop one standard at a time from my sample and re-run the regressions. I estimate 23 regressions for each of the four dependent variables and find that in 86 of the 92 regressions the coefficient for the interaction between Information and Unsigned Cumulative Effect is positive and statistically significant; all 92 coefficients are positive. The regressions suggest that the results documented in this paper are reasonably robust to excluding individual changes in GAAP from the analysis.

\subsection{Other Sensitivity Tests}

Lastly, I document that my results are robust to the following tests: 1) using future investment to examine the relation between change in GAAP and investment, 2) 
measuring the changes in GAAP using ranks and decile ranks of the Cumulative Effect rather than using raw continuous values, 3) controlling for year fixed effects, 4) controlling for year and industry fixed effects, and 5) controlling for accounting standard and industry fixed effects. Although the statistical significance of the regression coefficients drop when I simultaneously control for both industry and standard fixed effects, and industry and year fixed effects, I find that the general tenor of my inferences are unchanged. 


\section{CHAPTER 8}

\section{Conclusion}

My main objective in this study is to investigate whether changes in financial accounting rules affect managerial investment decisions and examine the mechanisms through which this economic consequence manifests. Using a sample containing fortynine changes in GAAP, I find robust evidence that accounting changes affect investment decisions. Specifically, I show that changes in accounting rules affect managerial investment in both physical and knowledge capital. In addition, I propose a novel reason why changes in accounting rules might affect managerial investment; I argue that accounting changes alter managers' information sets, which affects the NPV estimates of their investments and consequently the quantity and quality of their investment decisions. I provide evidence consistent with my hypothesis.

I also examine whether changes in accounting rules affect managerial investment because accounting numbers are used in contracts that do not fully accommodate changes in accounting rules (Holthausen and Leftwich, 1983; Watts and Zimmerman, 1986). I show that firms with financial covenants likely to be affected by accounting changes invest more (less) when the accounting change increases (decreases) covenant slack; further, I find that this relation is stronger when firm performance declines and renegotiation costs are likely to be high. This paper contributes to the literature on the real effects of accounting 
by showing that financial accounting rules affect investment decisions and by documenting specific mechanisms through which the relation manifests.

The findings in this paper might be of interest to managers and standard setters. Beatty (2007) argues "that for some, changes in management seem like an obvious consequence of accounting change, while for others the claims of behavioral changes are difficult, if not impossible, to prove." Beatty (2007) goes on to argue that there is even less consensus about the reasons for changes in managerial behavior and whether such changes are welfare enhancing or not. This study provides evidence that accounting changes do affect an important managerial decision and that some changes can even improve the quality of managerial decisions. Whether standard setters should consider the impact changes in GAAP have on economic behavior, and whether the improvement in managerial investment decisions results in a net benefit after considering the costs of the accounting change is beyond the scope of this paper. However, this study builds on our understanding of why accounting changes affect managerial behavior and provides some evidence that they can be welfare enhancing even when they do not improve financial reporting quality. 


\section{TABLE 4.1: Sample Selection}

This table reports the observation selection process and the number of firm-year observations used in my empirical analysis.

\begin{tabular}{lcc}
\hline \multicolumn{1}{c}{ Details } & $\begin{array}{c}\text { No Obs. } \\
\text { Dropped }\end{array}$ & $\begin{array}{c}\text { Obs. } \\
\text { Remaining }\end{array}$ \\
\hline \hline $\begin{array}{l}\text { Observations in the intersection of CRSP and Compustat with } \\
\text { fiscal years greater than } 1990 \text { and with non - zero values for the }\end{array}$ & & 5,530 \\
cumulative effect of an account change & 289 & 5,241 \\
Less: Observations missing data to compute average assets \\
$\quad \begin{array}{l}\text { Regulated \& financial firms (SIC's in the 4000's and } \\
\text { 6000's) }\end{array}$
\end{tabular}




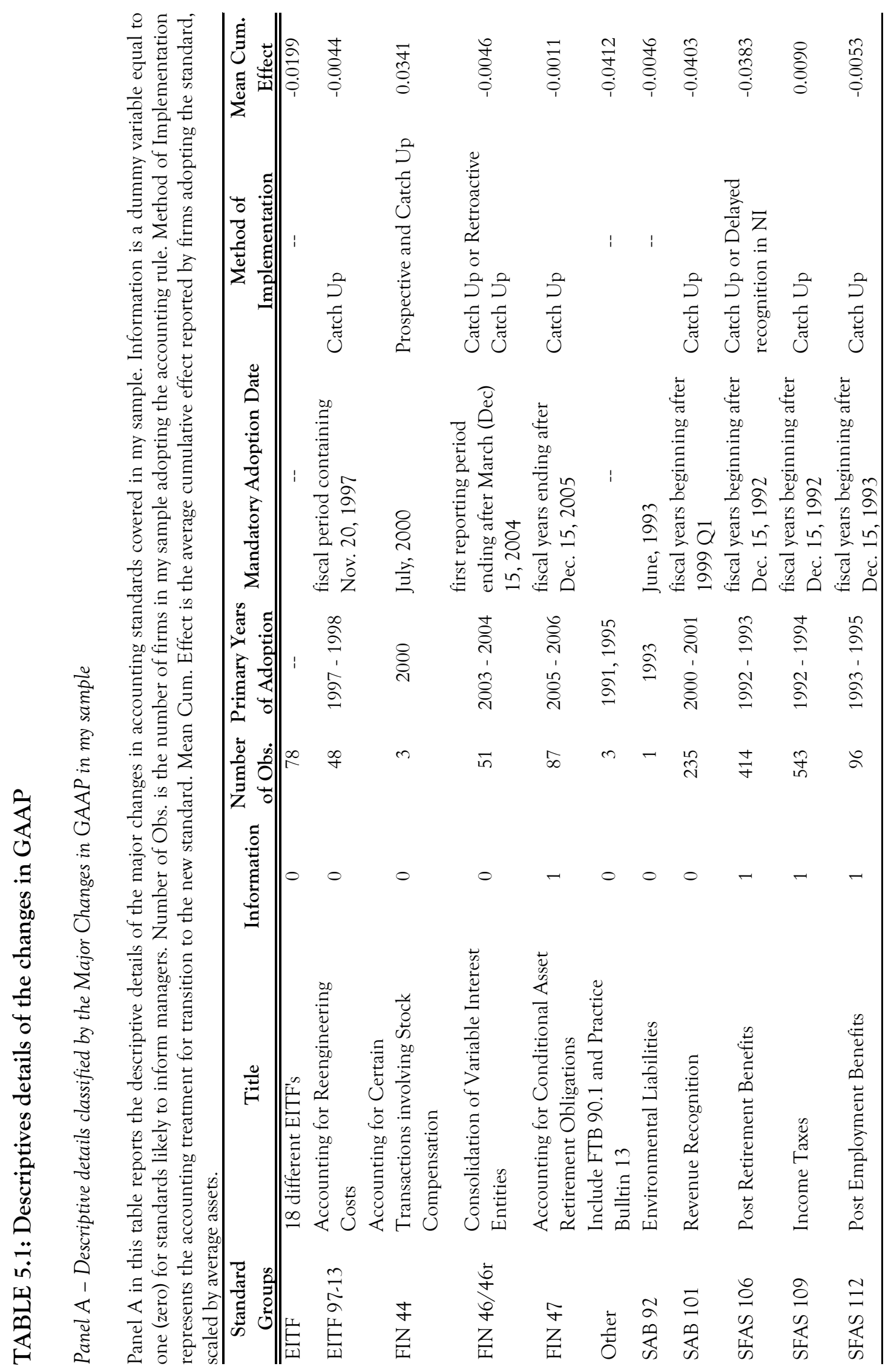




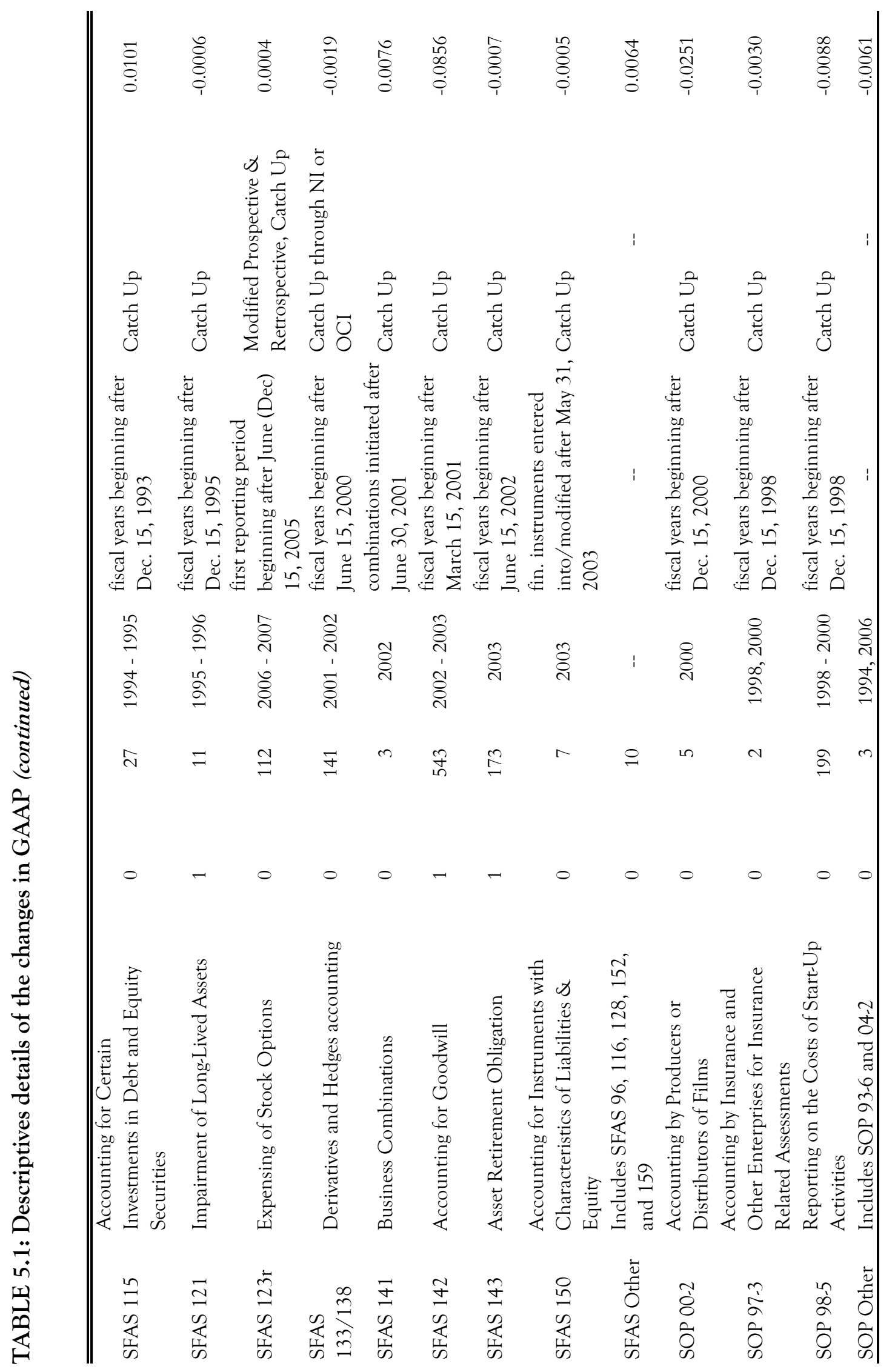




\section{TABLE 5.1: Descriptive details of changes in GAAP (continued)}

Panel B - Descriptive details classified by year

Panel $\mathrm{B}$ in this table reports which accounting pronouncements were adopted each year, along with the number of observations and the mean cumulative effect of an accounting change for the year in my sample. The mean cumulative effect is the within standard average cumulative effect of an accounting change.

\begin{tabular}{|c|c|c|c|c|}
\hline Year & $\begin{array}{l}\text { No. of } \\
\text { Obs. }\end{array}$ & $\begin{array}{c}\text { Mean Cumulative } \\
\text { Effect scaled by } \\
\text { average assets }\end{array}$ & $\begin{array}{c}\text { Mean } \\
\text { Cumulative } \\
\text { Effect (unscaled) }\end{array}$ & Accounting Standards \\
\hline 1991 & 42 & -0.0199 & -141.187 & SFAS 96, 106, 109; FTB 90.1 \\
\hline 1992 & 275 & -0.0291 & -139.654 & SFAS $106,109,112$ \\
\hline 1993 & 447 & -0.0081 & -41.899 & EITF 93.5; SAB 92; SFAS 106, 109, 112, 115 \\
\hline 1994 & 293 & 0.0035 & -6.215 & EITF 93.5; SOP 93.6; SFAS 106, 109, 112, 115 \\
\hline 1995 & 43 & 0.0010 & -12.478 & $\begin{array}{l}\text { EITF 95.1; Practice Bulletin 13; SFAS 109, 112, } \\
115,121\end{array}$ \\
\hline 1996 & 4 & -0.0128 & -1.666 & SFAS 121 \\
\hline 1997 & 36 & -0.0043 & -8.832 & EITF 97.13; SFAS 121; SOP 98.5 \\
\hline 1998 & 85 & -0.0103 & -5.950 & EITF 97.13; SFAS $121,128,133$; SOP 97.3, 98.5 \\
\hline 1999 & 109 & -0.0083 & -10.560 & SAB 101; SFAS 133; SOP 98.5 \\
\hline 2000 & 195 & -0.0404 & -17.278 & $\begin{array}{l}\text { EITF 0.27, 98.5, 99.5; FIN 44; SAB 101; SFAS } \\
\text { 133; SOP 0.2, 97.3, 98.5 }\end{array}$ \\
\hline 2001 & 229 & -0.0137 & -18.144 & EITF 0.19; SAB 101; SFAS 133; SOP 0.2 \\
\hline 2002 & 451 & -0.0838 & -161.660 & $\begin{array}{l}\text { EITF } 0.19,1.09,1.9,2.16 \text {; SFAS 133, 141, } 142 \text {, } \\
\text { 143; SOP } 0.2\end{array}$ \\
\hline 2003 & 337 & -0.0281 & -24.306 & EITF 0.21, 2.16, 3.4; FIN 46; SFAS 142, 143, 150 \\
\hline 2004 & 35 & -0.0100 & -194.843 & EITF 0.21, d108; FIN 46; SFAS 123r, 143, 150 \\
\hline 2005 & 70 & -0.0030 & -17.666 & EITF 4.6, d108; FIN 46, 47; SFAS 123r \\
\hline 2006 & 124 & -0.0005 & -10.684 & $\begin{array}{l}\text { EITF 0.192, 4.6, d108; FIN 47; SFAS 123r, 152; } \\
\text { SOP } 4.2\end{array}$ \\
\hline 2007 & 20 & 0.0022 & 0.964 & EITF 6.2; SFAS 123r, 159 \\
\hline
\end{tabular}




\section{TABLE 5.2: Summary Statistics of Variables used in the Regression Analysis}

This table presents descriptive statistics for the main variables used in my analysis. In the table above, Cumulative Effect (ACCHG) is the cumulative effect of an accounting change as reported in the income statement deflated by average assets in period $\mathrm{t}$ and $\mathrm{t}-1$. It represents effect of company adjustments due to accounting changes on all prior period earnings. Capital Expenditure (CAPX) is the cash outflow or the funds used for additions to the company's property, plant and equipment, excluding amounts arising from acquisitions, reported in the Statement of Cash Flows deflated by average assets in period $t$ and $t-1$. RED Expenditure (XRD) is the cost incurred during the year that relate to the development of new products or services deflated by average assets in period $\mathrm{t}$ and $\mathrm{t}-1$. RËD Expenditure is coded to zero if it is missing. Tobin's $Q$ is measured as the sum of market value of equity (PRCC_F x CSHO), short term debt (DLC) and long term debt (DLTT) divided by total assets (AT). Growth in Asset is the change in total assets (AT) from period $\mathrm{t}-1$ to period $\mathrm{t}$ scaled by total assets (AT) in period $\mathrm{t}-1$. Age [ $\operatorname{Ln}(\mathrm{Age})]$ is [the natural logarithm] of the difference between the first year the firm enters Compustat and the current year. Market Value of Equity [Ln(Market Value of Equity)] is the [natural logarithm] stock price at the end of the year (PRCC_F) times the number of shares outstanding (CSHO). Cash Flows from Operations (OANCF) is the cash flows from operations reported in the statement of cash flows deflated by average assets in period $t$ and $t-1$. Cash and Marketable securities (CHE) is cash and all securities readily transferable to cash deflated by average assets in period $t$ and $t-1$. Leverage is sum of short term debt (DLC) and long term debt (DLTT) deflated by average assets in period $\mathrm{t}$ and $\mathrm{t}-1$. Stock Returns (RET) in the total returns from investing in the stock of a company from period t -1 to period t. $\triangle$ Number of Analysts is the change in the number of analysts (NUMEST) following the firm as provided by IBES after the change in GAAP (i.e., change from t-1 to t). Analyst following is assumed to be zero if the firm is not covered by IBES. $\triangle$ Institutional Ownership is the change in the percentage of firms' shares held by institutional investors after the change in GAAP (i.e., change from t-1 to t). Institutional Ownership is assumed to be zero if the data are missing (notes continued on next page).

\begin{tabular}{|c|c|c|c|c|c|c|}
\hline Variable & Mean & Stdev & P5 & P50 & P95 & $\mathbf{N}$ \\
\hline \multicolumn{7}{|l|}{ INVESTMENT \& CHANGES IN GAAP } \\
\hline Cumulative Effect & -0.026 & 0.064 & -0.153 & -0.003 & 0.016 & 2,795 \\
\hline Capital Expenditure & 0.061 & 0.061 & 0.007 & 0.042 & 0.183 & 2,795 \\
\hline Research \& Development (R\&D) Expenditure & 0.033 & 0.065 & 0.000 & 0.000 & 0.167 & 2,795 \\
\hline \multicolumn{7}{|c|}{ DETERMINANTS OF INVESTMENT \& CONTROL VARIABLES } \\
\hline Tobin's Q & 1.321 & 1.024 & 0.454 & 1.006 & 3.363 & 2,795 \\
\hline Growth & 0.080 & 0.346 & -0.342 & 0.035 & 0.605 & 2,795 \\
\hline Age & 21.203 & 15.320 & 3 & 18 & 50 & 2,795 \\
\hline Ln(Age) & 2.714 & 0.898 & 1.099 & 2.890 & 3.912 & 2,795 \\
\hline Market Value of Equity & 3,263 & 9,274 & 9 & 372 & 16,631 & 2,795 \\
\hline Ln(Market Value of Equity) & 5.912 & 2.242 & 2.225 & 5.918 & 9.719 & 2,795 \\
\hline Cash Flow from Operations (CFO) & 0.067 & 0.113 & -0.128 & 0.076 & 0.225 & 2,795 \\
\hline Cash and Marketable securities & 0.129 & 0.188 & 0.003 & 0.054 & 0.537 & 2,795 \\
\hline Leverage & 0.256 & 0.199 & 0.000 & 0.235 & 0.631 & 2,795 \\
\hline Stock Returns & 0.104 & 0.603 & -0.680 & 0.028 & 1.152 & 2,795 \\
\hline \multicolumn{7}{|c|}{ CHANGE IN GOVERNANCE \& FINANCIAL REPORTING QUALITY } \\
\hline$\Delta$ Number of Analysts & -0.366 & 2.154 & -4.000 & 0.000 & 2.000 & 2,795 \\
\hline$\Delta$ Institutional Ownership & 0.011 & 0.073 & -0.101 & 0.000 & 0.127 & 2,795 \\
\hline$\Delta$ Financial Reporting Quality & 0.000 & 0.031 & -0.049 & 0.000 & 0.049 & 2,795 \\
\hline
\end{tabular}




\section{TABLE 5.2: Summary Statistics of Variables used in the Regression Analysis (continued)}

(continued...) $\Delta$ Financial Reporting Quality is the change in the Dechow and Dichev (2002) measure of reporting quality with the McNichols (2002) suggested modification, around the change in GAAP. Specifically, I estimate a regression of current accruals on past, current, and future cash flows, the change in sales, and gross PP\&E for each industry/year pool using all firms in Compustat and the Fama-French 30 industry classification scheme. The absolute value of the residual multiplied by minus one is my measure of reporting quality (for each firm-year). Since the Dechow-Dichev measure uses past and future cash flow data, I compute the change in reporting quality as reporting quality in period $t+1$ minus reporting quality in period t-1. Missing observations are assumed to have no change in reporting quality. $\Delta$ Capital Expenditure Efficiency - Sales Growth (4 Total Investment Efficiency - Sales Growth) is minus one multiplied by the change in the absolute value of the residuals from a regression of capital expenditure (capital $+R \& D$ expenditure) in period $t$ on sales growth in period $t-1$. The regression is estimated for each industry/year pool using all firms in Compustat and the Fama-French 30 industry classification scheme. The change in efficiency is the difference between the residual in period $\mathrm{t}+1$ and $\mathrm{t}-1$; period $\mathrm{t}$ is the year of the accounting change. $\Delta$ Capital Expenditure Efficiency - Q ( 4 Total Investment Efficiency - Q) is minus one multiplied by the change in the absolute value of the residuals from a regression of capital expenditure (capital $+R \& D$ expenditure) in period $\mathrm{t}$ on Tobin's $\mathrm{Q}$ in period $\mathrm{t}-1$ and Cash Flows from Operations in period t. The regression is estimated for each industry/year pool using all firms in Compustat and the Fama-French 30 industry classification scheme. The change in efficiency is the difference between the residual in period $t+1$ and $t-1$; period $t$ is the year of the accounting change. Information is a dummy variable equal to one for observations in which the firm adopted an accounting standard which is likely to provide managers with information; zero otherwise. The accounting standards classified as likely to provide information are described in Appendix A. Deal Scan is a dummy variable which takes on the value of one (zero) if the observation has (does not have) data available in the Dealscan database. Covenant is a dummy variable which takes on the value of one (zero) if the observation has (does not have) at least one financial covenant which is likely to be affected by the cumulative effect of an accounting change. Contracts with Fixed GAAP, Contracts with Hybrid GAAP, and Contracts with Floating GAAP are dummy variables which take on the value of one (zero) if the debt contract is based on Fixed, Hybrid, or Floating GAAP, respectively. Disclose Reconciliation is a dummy variable which equals one (zero) if the debt contract requires the firm to reconcile and disclose differences in financial ratios after changes in GAAP while renegotiating covenants. All continuous variables are winsorized at the 1\% and $99 \%$ of their empirical distribution.

\begin{tabular}{|c|c|c|c|c|c|c|}
\hline Variable & Mean & Stdev & P5 & P50 & P95 & $\mathrm{N}$ \\
\hline \multicolumn{7}{|l|}{ CHANGE IN INVESTMENT EFFICIENCY } \\
\hline$\Delta$ Capital Exp. Efficiency - Sales Growth & 0.0017 & 0.042 & -0.0540 & 0.0005 & 0.0634 & 2,591 \\
\hline$\Delta$ Total Investment Efficiency - Sales Growth & -0.0005 & 0.054 & -0.0805 & -0.0012 & 0.0801 & 2,591 \\
\hline$\Delta$ Capital Exp. Efficiency - Q & 0.0017 & 0.041 & -0.0536 & 0.0006 & 0.0602 & 2,627 \\
\hline$\Delta$ Total Investment Efficiency - Q & 0.0010 & 0.055 & -0.0761 & -0.0003 & 0.0838 & 2,627 \\
\hline \multicolumn{7}{|c|}{ INFORMATION AND DEBT CONTRACTING PROXIES } \\
\hline Information & 0.668 & 0.471 & 0 & 1 & 1 & 2,795 \\
\hline Organizational Complexity Index & -0.773 & 0.268 & -1.000 & -1.000 & -0.301 & 2,795 \\
\hline Deal Scan & 0.587 & 0.492 & 0 & 1 & 1 & 2,795 \\
\hline Covenant & 0.233 & 0.423 & 0 & 0 & 1 & 2,795 \\
\hline Contracts with Fixed GAAP & 0.439 & 0.497 & 0 & 0 & 1 & 371 \\
\hline Contracts with Hybrid GAAP & 0.358 & 0.480 & 0 & 0 & 1 & 371 \\
\hline Contracts with Floating GAAP & 0.202 & 0.402 & 0 & 0 & 1 & 371 \\
\hline Disclose Reconciliation & 0.054 & 0.226 & 0 & 0 & 1 & 371 \\
\hline
\end{tabular}




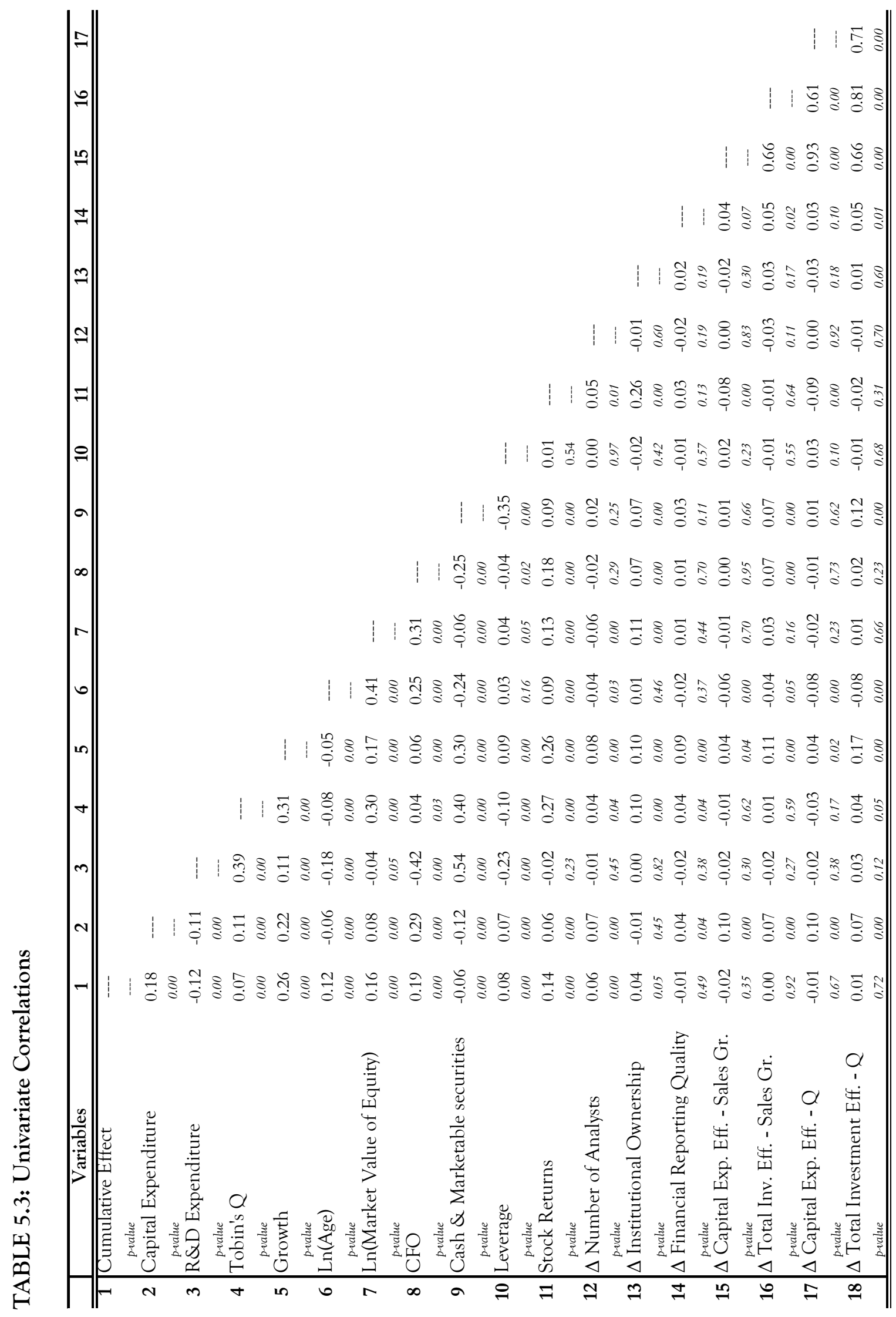




\section{TABLE 5.4: Regression Analysis: Tests of Hypothesis One}

This table presents the results from regressing investment on various determinants of investment and the Cumulative Effect. I use OLS to estimate the regression equations with Capital Expenditure as the dependent variable, and I use the Tobit model to estimate the regression equations with REBD Expenditure as the dependent variable. The table reports the coefficients for the Capital Expenditure regressions and the marginal effects for the REBD Expenditure regressions. The marginal effects reported represent the change in expected $R \mathcal{E D}$ Expenditure with respect to a change in the independent variable, conditioned on RED Expenditure being greater than zero and the covariates, that is, $\partial \mathrm{E}(\mathrm{Y} \mid \mathrm{X}, \mathrm{Y}>0) / \partial \mathrm{XX}$. The t-statistics are reported in parentheses. Refer to Appendix B or prior tables for variable definitions. All continuous variables are winsorized at the $1 \%$ and $99 \%$ of their empirical distribution. ${ }^{* * *},{ }^{* *}$, and ${ }^{*}$ denote statistical significance at the one (two) tailed $1 \%, 5 \%$, and $10 \%$ levels when I (do not) have a directional prediction.

\begin{tabular}{|c|c|c|c|c|c|}
\hline Dependent Variable & $\begin{array}{l}\text { Predicted } \\
\text { Sign }\end{array}$ & $\begin{array}{c}\text { Capital } \\
\text { Expenditure }_{\mathrm{t}} \\
(\mathrm{t}-\text { statistic })^{-} \\
\end{array}$ & $\begin{array}{c}\mathrm{R} \& \mathrm{D} \\
\text { Expenditure }_{\mathrm{t}} \\
(\mathrm{t}-\text { statistic })\end{array}$ & $\begin{array}{c}\text { Capital } \\
\text { Expenditure }_{\mathrm{t}} \\
(\mathrm{t}-\text { statistic })^{-} \\
\end{array}$ & $\begin{array}{c}R \& D \\
\text { Expenditure }_{t} \\
(t-\text { statistic }) \\
\end{array}$ \\
\hline $\begin{array}{c}\text { Cumulative Effect } \\
t\end{array}$ & + & $\begin{array}{l}0.044 \text { *** } \\
(4.65)\end{array}$ & $\begin{array}{l}0.016^{* * *} \\
(5.15)\end{array}$ & $\begin{array}{l}0.017 \text { *** } \\
(3.39)\end{array}$ & $\begin{array}{l}0.014 \text { *** } \\
(2.23)\end{array}$ \\
\hline Tobin's $Q_{t-1}$ & & $\begin{array}{l}0.006^{* * *} \\
(8.18)\end{array}$ & $\begin{array}{l}0.002 \text { *** } \\
(6.65)\end{array}$ & $\begin{array}{l}0.005^{* * *} \\
(6.77)\end{array}$ & $\begin{array}{l}0.003 \text { *** } \\
(5.63)\end{array}$ \\
\hline $\mathrm{CFO}_{\mathrm{t}}$ & & $\begin{array}{l}0.065 \text { *** } \\
(3.45)\end{array}$ & $\begin{array}{l}-0.013 \text { ** } \\
(-2.04)\end{array}$ & $\begin{array}{l}0.082 \text { *** } \\
(4.41)\end{array}$ & $\begin{array}{l}-0.016 * * \\
(-2.00)\end{array}$ \\
\hline Cash $_{\mathrm{t}-1}$ & & $\begin{array}{l}-0.008 * \\
(-1.75)\end{array}$ & $\begin{array}{l}-0.002 \\
(-0.50)\end{array}$ & $\begin{array}{l}-0.006 \\
(-1.03)\end{array}$ & $\begin{array}{l}-0.005 \\
(-1.11)\end{array}$ \\
\hline Growth $_{\mathrm{t}-1}$ & & $\begin{array}{l}0.012 \text { *** } \\
(3.55)\end{array}$ & $\begin{array}{l}0.003 * * * \\
(3.41)\end{array}$ & $\begin{array}{l}0.011 \text { *** } \\
(3.14)\end{array}$ & $\begin{array}{l}0.004 \text { *** } \\
(3.69)\end{array}$ \\
\hline $\operatorname{Ln}\left(\right.$ Age $\left._{t}\right)$ & & $\begin{array}{l}0.000 \\
(0.03)\end{array}$ & $\begin{array}{l}0.000 \\
(1.04)\end{array}$ & $\begin{array}{l}-0.001 \\
(-1.35)\end{array}$ & $\begin{array}{l}0.002^{* * *} \\
(4.43)\end{array}$ \\
\hline Leverage $_{t}$ & & $\begin{array}{l}0.001 \\
(0.21)\end{array}$ & $\begin{array}{l}-0.007^{* * *} \\
(-2.91)\end{array}$ & $\begin{array}{l}0.007 \\
(1.09)\end{array}$ & $\begin{array}{l}-0.010 \text { *** } \\
(-3.35)\end{array}$ \\
\hline $\operatorname{Ln}($ Market Value of Equity $)$ & & $\begin{array}{l}-0.001 * * \\
(-2.27)\end{array}$ & $\begin{array}{l}0.001 * * * \\
(4.81)\end{array}$ & $\begin{array}{l}-0.001 \\
(-1.44)\end{array}$ & $\begin{array}{l}0.001 \text { *** } \\
(4.34)\end{array}$ \\
\hline Stock Returns $_{t}$ & & $\begin{array}{l}0.005 \text { ** } \\
(2.35)\end{array}$ & $\begin{array}{l}0.002 \\
(1.56)\end{array}$ & $\begin{array}{l}0.005 \text { ** } \\
(2.45)\end{array}$ & $\begin{array}{l}0.002 \\
(1.41)\end{array}$ \\
\hline Capital Expenditure $_{t-1}$ & & $\begin{array}{l}0.625 \text { *** } \\
(22.46)\end{array}$ & --- & $\begin{array}{l}0.714 \text { *** } \\
(23.51)\end{array}$ & --- \\
\hline$R \& D$ Expenditure $_{t-1}$ & & --- & $\begin{array}{l}0.343 \text { *** } \\
(10.83)\end{array}$ & --- & $\begin{array}{l}0.487^{* * *} \\
(9.20)\end{array}$ \\
\hline Clustered Std. Errors & & Firm \& Year & Year & Firm \& Year & Year \\
\hline Industry Fixed Effects & & Yes & Yes & No & No \\
\hline Accounting Standard Fixed Effec & & No & No & Yes & Yes \\
\hline Number of Observations & & 2,795 & 2,795 & 2,795 & 2,795 \\
\hline Adj./Pseudo R-Square & & 0.59 & 0.91 & 0.57 & 0.90 \\
\hline
\end{tabular}




\section{TABLE 5.5: Regression Analysis: Tests of Hypothesis Two, Part A}

This table presents the results from regressing investment on various determinants of investment, Information, and the Cumulative Effect. I use OLS to estimate the regression equations with Capital Expenditure as the dependent variable, and I use the Tobit model to estimate the regression equations with REDD Expenditure as the dependent variable. The table reports the coefficients for the Capital Expenditure regressions and the marginal effects for the REED Expenditure regressions. The marginal effects reported represent the change in expected REED Expenditure with respect to a change in the independent variable, conditioned on RED Expenditure being greater than zero and the covariates, that is, $\mathrm{\partial E}(\mathrm{Y} \mid \mathrm{X}, \mathrm{Y}>0) / \partial \mathrm{X}$. The t-statistics are reported in parentheses. Information is a dummy variable which takes on the value of one for observations in which the firm adopted an accounting standard which is likely to inform managers about current or future investment opportunities. It takes on the value of zero otherwise. The accounting standards classification is described in Appendix A. No Information is a dummy variable which takes on the value of one (zero) if Information equals zero (one). Refer to Appendix B or prior tables for variable definitions. All continuous variables are winsorized at the $1 \%$ and $99 \%$ of their empirical distribution. ${ }^{* *}$, ${ }^{* *}$, and ${ }^{*}$ denote statistical significance at the one (two) tailed 1\%, 5\%, and 10\% levels when I (do not) have a directional prediction.

\begin{tabular}{|c|c|c|c|}
\hline Dependent Variable & Predicted Sign & $\begin{array}{c}\text { Capital Expenditure }_{\mathrm{t}} \\
(\mathrm{t}-\text { statistic })\end{array}$ & $\begin{array}{c}\text { R\&D Expenditure }{ }_{t} \\
(t-\text { statistic })\end{array}$ \\
\hline \multirow{2}{*}{ Information x Cumulative Effect ${ }_{t}$} & + & $0.053 * * *$ & $0.017^{* * *}$ \\
\hline & & $(4.23)$ & $(4.21)$ \\
\hline \multirow{2}{*}{ No Information x Cumulative Effect ${ }_{t}$} & $?$ & -0.012 & 0.009 \\
\hline & & $(-0.33)$ & $(0.58)$ \\
\hline \multirow[t]{2}{*}{ Tobin's $Q_{t-1}$} & & $0.005 * * *$ & $0.002 * * *$ \\
\hline & & $(8.10)$ & $(6.13)$ \\
\hline \multirow[t]{2}{*}{$\mathrm{CFO}_{\mathrm{t}}$} & & $0.069 * * *$ & $-0.012 *$ \\
\hline & & $(3.86)$ & $(-1.83)$ \\
\hline \multirow[t]{2}{*}{ Cash $_{\mathrm{t}-1}$} & & $-0.007 *$ & -0.002 \\
\hline & & $(-1.90)$ & $(-0.54)$ \\
\hline \multirow[t]{2}{*}{ Growth $_{\mathrm{t}-1}$} & & $0.012 * * *$ & $0.003 * * *$ \\
\hline & & $(3.24)$ & $(3.40)$ \\
\hline \multirow[t]{2}{*}{$\operatorname{Ln}\left(\right.$ Age $\left._{t}\right)$} & & 0.000 & 0.000 \\
\hline & & $(-0.09)$ & $(0.99)$ \\
\hline \multirow[t]{2}{*}{ Leverage $_{t}$} & & 0.001 & $-0.008 * * *$ \\
\hline & & $(0.22)$ & $(-2.96)$ \\
\hline \multirow[t]{2}{*}{ Ln(Market Value of Equity $\left.{ }_{t}\right)$} & & $-0.001 * *$ & $0.001 * * *$ \\
\hline & & $(-2.26)$ & $(4.43)$ \\
\hline \multirow[t]{2}{*}{ Stock Returns $_{t}$} & & $0.005 * *$ & 0.002 \\
\hline & & $(2.21)$ & $(1.46)$ \\
\hline \multirow[t]{2}{*}{ Information $_{\mathrm{t}}$} & & 0.000 & 0.000 \\
\hline & & $(0.09)$ & $(-0.70)$ \\
\hline \multirow[t]{2}{*}{ Capital Expenditure $_{\mathrm{t}-1}$} & & $0.623 * * *$ & -- \\
\hline & & $(22.79)$ & \\
\hline \multirow[t]{2}{*}{$R \& D$ Expenditure $_{t-1}$} & & --- & $0.342 * * *$ \\
\hline & & & $(10.60)$ \\
\hline Clustered Std. Errors & & Firm \& Year & Year \\
\hline Industry Fixed Effects & & Yes & Yes \\
\hline Number of Observations & & 2,795 & 2,795 \\
\hline Adj./Pseudo K-Sqquare & & 0.59 & 0.91 \\
\hline
\end{tabular}




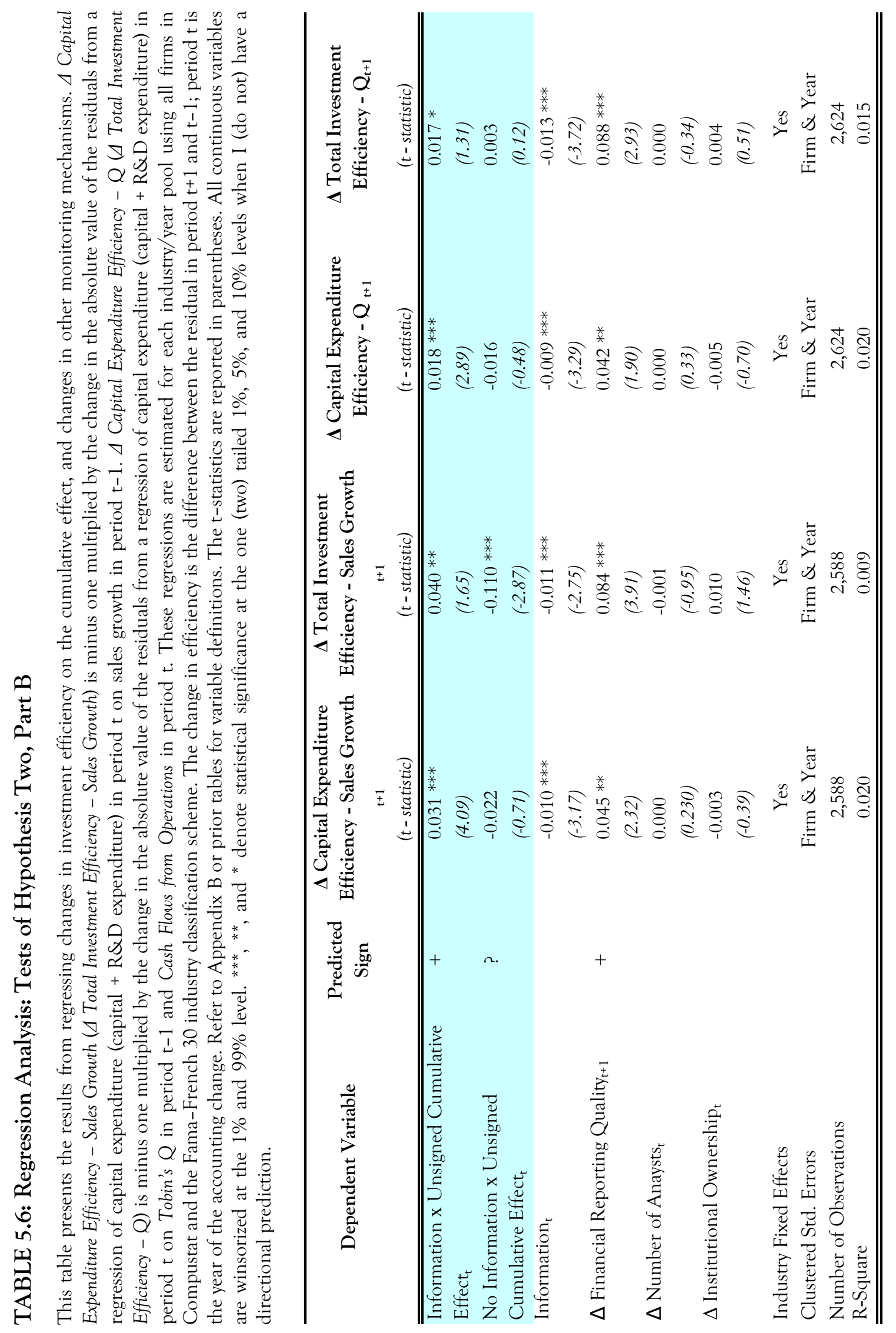




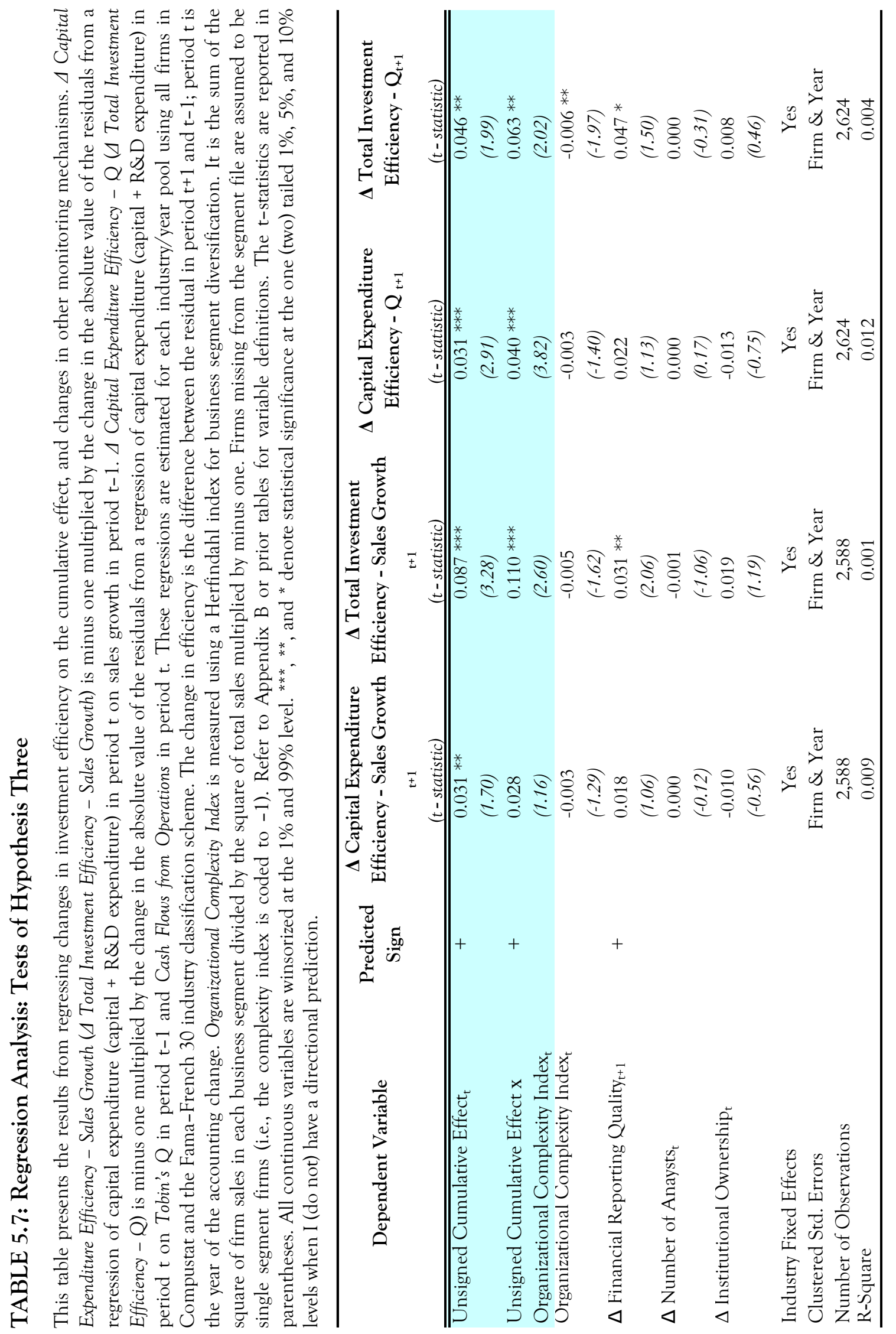




\section{TABLE 5.8: Regression Analysis: Main Tests of Hypothesis Four}

This table presents the results from regressing investment on various determinants of investment, Covenants, the type of GAAP used in contracts, and the Cumulative Effect. I use OLS (Tobit) to estimate the regression equations with Capital (REDD) Expenditure as the dependent variable. The table reports the coefficients for the Capital Expenditure regressions and the marginal effects for the RED Expenditure regressions. Covenant is an indicator variable which takes on the value of one if the observation has at least one financial covenant which is likely to be affected by the cumulative effect of an accounting change. No Covenant is an indicator variable which takes on the value of one if Covenant equals zero. Floating GAAP is an indicator variable that takes on the value of one if the debt agreement uses the Floating GAAP practice or requires the firm to disclose reconciliations between the old and new accounting practice while renegotiating covenants to adjust for the change in GAAP. No Floating GAAP is an indicator variable that takes on the value of one if Floating GAAP equals zero. The t-statistics are reported in parentheses. Refer to Appendix B or prior tables for variable definitions. All continuous variables are winsorized at the $1 \%$ and $99 \%$ level. ${ }^{* * *}$, ${ }^{* *}$, and ${ }^{*}$ denote statistical significance at the one (two) tailed $1 \%, 5 \%$, and $10 \%$ levels when I (do not) have a directional prediction.

\begin{tabular}{|c|c|c|c|c|c|}
\hline \multirow[t]{2}{*}{ Dependent Variable } & \multirow{2}{*}{$\begin{array}{l}\text { Predicted } \\
\text { Sign } \\
\end{array}$} & \multicolumn{2}{|c|}{ Capital Expenditure $_{t}$} & \multicolumn{2}{|c|}{ R\&D Expenditure $t_{t}$} \\
\hline & & $(t-$ statistic $)$ & $(t-$ statistic $)$ & $(t-$ statistic $)$ & $(t-$ statistic $)$ \\
\hline \multicolumn{6}{|c|}{ Panel A: Regressions with Industry Fixed Effects } \\
\hline Covenants x Cumulative Effect $t_{t}$ & + & $\begin{array}{l}0.035 \text { *** } \\
(2.43)\end{array}$ & --- & $\begin{array}{l}0.009 * \\
(1.61)\end{array}$ & --- \\
\hline $\begin{array}{l}\text { Floating GAAP x Covenants x } \\
\text { Cumulative Effect } t_{t}\end{array}$ & + & --- & $\begin{array}{l}0.073 \text { *** } \\
(2.85)\end{array}$ & --- & $\begin{array}{l}0.029^{* * *} \\
(3.20)\end{array}$ \\
\hline $\begin{array}{l}\text { No Floating GAAP x Covenants } \\
\text { x Cumulative Effect }\end{array}$ & $?$ & --- & $\begin{array}{l}0.056^{* * *} \\
(3.75)\end{array}$ & --- & $\begin{array}{l}0.008 \\
(1.04)\end{array}$ \\
\hline No Covenants $_{t}$ & & 0.003 & 0.004 & 0.001 & 0.001 \\
\hline Floating GAAP x Covenants ${ }_{t}$ & & $\begin{array}{c}(0.94) \\
---\end{array}$ & $\begin{array}{l}(1.16) \\
0.007 \\
(1.47)\end{array}$ & $\begin{array}{c}(1.56) \\
---\end{array}$ & $\begin{array}{l}(1.62) \\
0.000 \\
(0.03)\end{array}$ \\
\hline $\begin{array}{l}\text { No Covenants x Cumulative } \\
\text { Effect }_{t}\end{array}$ & & $\begin{array}{l}0.044^{* * *} \\
(3.93)\end{array}$ & $\begin{array}{l}0.044 * * * \\
(4.20)\end{array}$ & $\begin{array}{l}0.017 \text { *** } \\
(5.18)\end{array}$ & $\begin{array}{l}0.016 * * * \\
(4.08)\end{array}$ \\
\hline Adj./Pseudo R-Square & & 0.593 & 0.601 & 0.912 & 0.906 \\
\hline \multicolumn{6}{|c|}{ Panel B: Regressions with Accounting Standard Fixed Effects } \\
\hline Covenants x Cumulative Effect $t_{t}$ & + & $\begin{array}{l}0.011 \\
(0.83)\end{array}$ & --- & $\begin{array}{l}0.000 \\
(0.05)\end{array}$ & --- \\
\hline $\begin{array}{l}\text { Floating GAAP x Covenants x } \\
\text { Cumulative Effect }\end{array}$ & + & --- & $\begin{array}{l}0.053^{* *} \\
(1.88)\end{array}$ & --- & $\begin{array}{l}0.036 \text { *** } \\
(2.35)\end{array}$ \\
\hline $\begin{array}{l}\text { No Floating GAAP x Covenants } \\
\text { x Cumulative Effect } t_{t}\end{array}$ & $?$ & --- & $\begin{array}{l}0.029 \\
(1.46)\end{array}$ & --- & $\begin{array}{l}-0.005 \\
(-0.34)\end{array}$ \\
\hline No Covenants $_{t}$ & & 0.000 & 0.000 & 0.001 & 0.001 \\
\hline Floating GAAP x Covenants ${ }_{t}$ & & $\begin{array}{c}(-0.13) \\
---\end{array}$ & $\begin{array}{l}(-0.08) \\
0.007 \\
(1.55)\end{array}$ & $\begin{array}{c}(0.69) \\
---\end{array}$ & $\begin{array}{l}(0.79) \\
0.000 \\
(-0.15)\end{array}$ \\
\hline $\begin{array}{l}\text { No Covenants x Cumulative } \\
\text { Effect }_{t}\end{array}$ & & $\begin{array}{l}0.019 \text { *** } \\
(2.89)\end{array}$ & $\begin{array}{l}0.023 * * * \\
(3.08)\end{array}$ & $\begin{array}{l}0.017 \text { ** } \\
(2.19)\end{array}$ & $\begin{array}{l}0.016 * \\
(1.84)\end{array}$ \\
\hline Adj./Pseudo R-Square & & 0.573 & 0.582 & 0.903 & 0.896 \\
\hline $\begin{array}{l}\text { Control Variables } \\
\text { Clustered Std. Errors } \\
\text { Number of Observations }\end{array}$ & & $\begin{array}{c}\text { Yes } \\
\text { Firm \& Year } \\
2,795\end{array}$ & $\begin{array}{c}\text { Yes } \\
\text { Firm \& Year } \\
2,514\end{array}$ & $\begin{array}{l}\text { Yes } \\
\text { Year } \\
2,795\end{array}$ & $\begin{array}{l}\text { Yes } \\
\text { Year } \\
2,514\end{array}$ \\
\hline
\end{tabular}




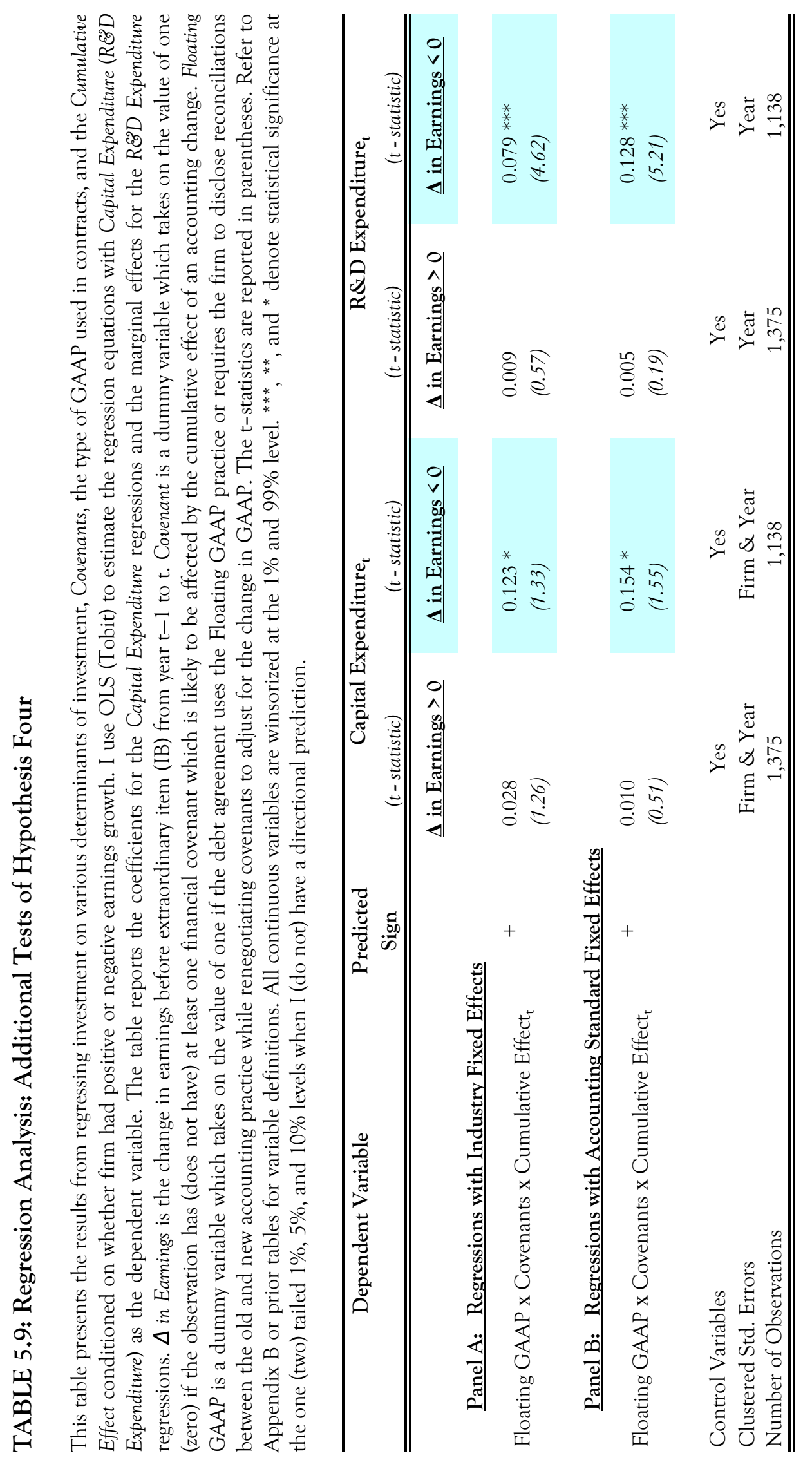




\section{TABLE 7.1: Robustness Tests}

This table reports the results from regressing investment on the determinants of investment and the Cumulative Effect. The Cumulative Effect is split into four parts capturing all combinations of the variables: Information, No Information, Floating GAAP Covenants, and No Floating GAAP Covenants. Floating GAAP Covenants is a dummy variable which takes on the value of one if the firm has at least one financial covenant which is likely to be affected by the cumulative effect of an accounting change and the debt agreement uses the Floating GAAP practice or requires the firm to disclose reconciliations between the old and new accounting practice while renegotiating covenants to adjust for the change in GAAP. No Floating GAAP Covenants is a dummy variable which takes on the value of one (zero) if Floating GAAP Covenants equals zero (one). Information is a dummy variable which takes on the value of one for observations in which the firm adopted an accounting standard which is likely to inform managers about current or future investment opportunities. It takes on the value of zero otherwise. The accounting standards classification is described in Appendix A. No Information is a dummy variable which takes on the value of one (zero) if Information equals zero (one). I use OLS (Tobit) to estimate the regression equations with Capital Expenditure (REDD Expenditure) as the dependent variable. The table reports the coefficients for the Capital Expenditure regressions and the marginal effects for the REDD Expenditure regressions. The marginal effects reported represent the change in expected RED Expenditure with respect to a change in the independent variable, conditioned on RED Expenditure being greater than zero and the covariates, that is, $\partial E(Y \mid X, Y>0) / \partial X$. The $t$-statistics are reported in parentheses. Refer to Appendix B or prior tables for variable definitions. The regressions include the control variables used in prior tables but the coefficients are suppressed. All continuous variables are winsorized at the $1 \%$ and $99 \%$ of their empirical distribution. ${ }^{* * *},{ }^{* *}$, and ${ }^{*}$ denote statistical significance at the one (two) tailed 1\%, 5\%, and 10\% levels when I (do not) have a directional prediction.

\begin{tabular}{|c|c|c|c|}
\hline Dependent Variable & $\begin{array}{l}\text { Predicted } \\
\text { Sign }\end{array}$ & $\begin{array}{l}\text { Capital } \\
\text { Expenditure }_{t} \\
(t-\text { statistic })^{2}\end{array}$ & $\begin{array}{c}\text { R\&D } \\
\text { Expenditure }_{t} \\
(t-\text { statistic }) \\
\end{array}$ \\
\hline \multirow{2}{*}{ Information x Floating GAAP Covenants ${ }_{t}$} & & -0.003 & 0.000 \\
\hline & & $(-0.93)$ & $(-0.22)$ \\
\hline \multirow[t]{2}{*}{ Information x No Floating GAAP Covenants $_{t}$} & & 0.003 & -0.001 \\
\hline & & $(1.06)$ & $(-1.04)$ \\
\hline \multirow{2}{*}{ No Information x No Floating GAAP Covenants ${ }_{t}$} & & $0.014 *$ & -0.003 \\
\hline & & $(1.96)$ & $(-1.44)$ \\
\hline \multirow{2}{*}{$\begin{array}{l}\text { Information x Floating GAAP Covenants x Cumulative } \\
\text { Effect }_{t}\end{array}$} & + & $0.030 *$ & $0.047 * * *$ \\
\hline & & $(1.75)$ & $(7.30)$ \\
\hline \multirow{2}{*}{$\begin{array}{l}\text { Information x No Floating GAAP Covenants x Cumulative } \\
\text { Effect }_{t}\end{array}$} & + & $0.057 * * *$ & $0.015 * * *$ \\
\hline & & $(4.55)$ & $(4.18)$ \\
\hline \multirow{2}{*}{$\begin{array}{l}\text { No Information x Floating GAAP Covenants x Cumulative } \\
\text { Effect }_{\mathrm{t}}\end{array}$} & + & -0.039 & -0.029 \\
\hline & & $(-0.19)$ & $(-0.23)$ \\
\hline \multirow{2}{*}{$\begin{array}{l}\text { No Information x No Floating GAAP Covenants x } \\
\text { Cumulative Effect } \\
\text { t }\end{array}$} & $?$ & 0.000 & 0.016 \\
\hline & & $(-0.01)$ & $(0.86)$ \\
\hline \multirow{2}{*}{\multicolumn{2}{|c|}{$\begin{array}{l}\text { Joint signifcance of Information x Cumulative Effect (two } \\
\text { tailed p-value) } \\
\text { Joint signifcance of Floating GAAP Covenants x Cumulative } \\
\text { Effect (two tailed p-value) }\end{array}$}} & 0.000 & 0.000 \\
\hline & & 0.963 & 0.889 \\
\hline \multicolumn{2}{|l|}{ Control Variables } & Yes & Yes \\
\hline \multicolumn{2}{|l|}{ Clustered Std. Errors } & Firm \& Year & Year \\
\hline \multicolumn{2}{|l|}{ Industry Fixed Effects } & Yes & Yes \\
\hline \multicolumn{2}{|l|}{ Number of Observations } & 2,514 & 2,514 \\
\hline \multicolumn{2}{|l|}{ Adj./Pseudo R-Square } & 0.60 & 0.91 \\
\hline
\end{tabular}




\section{APPENDIX A}

\section{Identifying Changes in GAAP that are likely to inform Managers}

Hypotheses $2 \mathrm{a}$ and $2 \mathrm{~b}$ predict that some accounting changes can inform managers and facilitate their investment decisions. A crucial component of this test is identifying which changes in GAAP are more or less likely to inform managers. I discuss my identification choices for the thirteen standards that were adopted by at least 25 firms in my sample. Collectively, these thirteen standards comprise more than 95\% of my sample. To identify standards more likely to inform managers, I examine whether the change in GAAP increased the amount of accrual accounting estimates and judgment that managers are required to make and I examine whether compliance with the standard is likely to require the services of an outside expert (e.g., actuary or appraiser). Managers require information to arrive at reasonable estimates of the numbers reported in public financial statements. Therefore, standards that increase the amount of judgment and estimation managers are required to make are more likely than others to require additional information collection and to inform managers. ${ }^{34}$

\begin{tabular}{|c|c|c|}
\hline $\begin{array}{l}\text { Reporting } \\
\text { Rule }\end{array}$ & Classification & Discussion of the Accounting Standard Classification Choices \\
\hline $\begin{array}{c}\text { SFAS No. 106: } \\
\text { Accounting for } \\
\text { post retirement } \\
\text { benefits other } \\
\text { than pensions }\end{array}$ & Informative & $\begin{array}{l}\text { SFAS } 106 \text { establishes accounting standards for employers' accounting for } \\
\text { postretirement benefits other than pensions. Prior to SFAS } 106 \\
\text { accounting for postretirement benefits was based on a pay-as-you-go (cash) } \\
\text { basis. SFAS } 106 \text { required firms to accrue the expected cost of providing } \\
\text { future benefits to an employee over the years that the employee renders } \\
\text { service. The change required firms to compute the expected duration for } \\
\text { which an employee will serve the company, the future cost of providing } \\
\text { promised benefits, the expected life of the employee postretirement, etc. } \\
\text { These calculations likely provided managers with richer and more } \\
\text { accurate information about the cost of promised benefits and more } \\
\text { generally, the cost of an employee's service. Any re-evaluation of } \\
\text { employee costs is likely to have factored into investment decisions as it } \\
\text { directly affects the net present value of the investment. }\end{array}$ \\
\hline
\end{tabular}

\footnotetext{
${ }^{34}$ I validate my classification procedure for changes in GAAP using a returns based test described in Section 3.4 .

35 Amir (1993) shows that investors underestimated the full consequences of post retirement benefits promised by firms prior to the introduction of SFAS 106. He goes on to shows that disclosures required by SFAS 106 are value-relevant and they help investors compute a more accurate value of the cost of post retirement benefits.
} 


\begin{tabular}{|c|c|c|}
\hline $\begin{array}{l}\text { SFAS No. 109: } \\
\text { Accounting for } \\
\text { income taxes }\end{array}$ & Informative & $\begin{array}{l}\text { SFAS } 109 \text { required firms to recognize deferred tax liabilities (assets) for } \\
\text { all taxable (deductible) temporary differences (and operating loss and tax } \\
\text { credit carryforwards). Further, based on the available evidence, deferred } \\
\text { tax assets should be reduced by a valuation allowance to amounts more } \\
\text { likely than not to be realized in future tax returns. The realization of } \\
\text { deferred tax assets depends primarily on the existence of sufficient } \\
\text { taxable income of appropriate character. Such taxable income is } \\
\text { generated from 1) reversal of existing taxable temporary differences, 2) } \\
\text { any future taxable income exclusive of reversing temporary differences, 3) } \\
\text { taxable income in carry back years, and 4) tax-planning strategies (see } \\
\text { Miller and Skinner, 1998). Considering future economic events in } \\
\text { assessing the likelihood of realizing the deferred tax asset is a unique } \\
\text { provision of SFAS } 109 \text { and Ayers (1998) shows that this information is } \\
\text { value-relevant to investors. The information necessary to estimate future } \\
\text { tax consequences of current transactions could potentially provide } \\
\text { managers with better estimates of marginal tax rates and hence, affect } \\
\text { investment decisions. }\end{array}$ \\
\hline $\begin{array}{l}\text { SFAS No. 112: } \\
\text { Accounting for } \\
\text { post employment } \\
\text { benefits }\end{array}$ & Informative & $\begin{array}{l}\text { SFAS } 112 \text { establishes accounting standards for employers who provide } \\
\text { benefits to former or inactive employees after employment but before } \\
\text { retirement. This statement required firm to recognize of the cost of } \\
\text { postemployment benefits on an accrual basis (when it could be } \\
\text { reasonable estimated). Prior to this Statement, employers' accounting for } \\
\text { the cost of postemployment benefits varied. Some employers accrued the } \\
\text { estimated cost of those benefits over the related service periods of active } \\
\text { employees, and other employers recognized the cost of postemployment } \\
\text { benefits when they were paid (cash basis). Employers using the cash basis } \\
\text { of accounting for post employment benefits likely required more } \\
\text { information to obtain reasonable accrual estimates. Hence, this statement } \\
\text { potentially created information for firms who used the cash basis of } \\
\text { accounting for post employment benefits. }{ }^{36}\end{array}$ \\
\hline $\begin{array}{l}\text { SFAS No. 115: } \\
\text { Accounting for } \\
\quad \text { certain } \\
\text { investments in } \\
\text { Debt and Equity } \\
\quad \text { Securities }\end{array}$ & $\begin{array}{c}\text { Not } \\
\text { Informative }\end{array}$ & $\begin{array}{l}\text { SFAS } 115 \text { addresses the accounting for investments in equity securities } \\
\text { that have readily determinable fair values and for all investments in debt } \\
\text { securities. This standard did not require the collection of any new } \\
\text { information, rather, it required firms to classify securities into three } \\
\text { groups-held-to-maturity, available-for-sale, and trading securities- } \\
\text { depending on the intent of purchase. }\end{array}$ \\
\hline $\begin{array}{c}\text { EITF 97-13: } \\
\text { Accounting for } \\
\text { Consulting } \\
\text { Contracts, } \\
\text { Business Process } \\
\text { Reengineering } \mathbb{E} \\
\text { IT } \\
\text { Transformation }\end{array}$ & $\begin{array}{c}\text { Not } \\
\text { Informative }\end{array}$ & $\begin{array}{l}\text { EITF 97-13 concerns accounting for costs incurred in connection with a } \\
\text { consulting contract or an internal project that combines business process } \\
\text { reengineering and information technology transformation. Prior to this } \\
\text { rule, the reporting practices of various firms were mixed. Some firms } \\
\text { capitalized the cost associated with business process reengineering while } \\
\text { other firms expensed them. This accounting change required firms to } \\
\text { expense the cost of business process reengineering activities as incurred. } \\
\text { Since expensing the cost of an activity is unlikely to require information } \\
\text { collection. Rather, in most cases, expensing an item which was previously }\end{array}$ \\
\hline
\end{tabular}

\footnotetext{
${ }^{36}$ Firms already using the accrual basis of accounting for post employment benefits are likely to have smaller transition obligations from adopting this standard. Since I use the transition obligation to measure the impact of a standard on the firm, the fact that some firms already used the accrual method is unlikely to be a cause for concern.
} 


\begin{tabular}{|c|c|c|}
\hline & & $\begin{array}{l}\text { capitalized simply amounts to removing the item from the balance sheet } \\
\text { and including it in the income statement. Hence, the adoption of this } \\
\text { rule is unlikely to generate decision facilitating information for managers. }\end{array}$ \\
\hline $\begin{array}{l}\text { SOP 98-5: } \\
\text { Reporting on the } \\
\text { Costs of Start- } \\
\text { Up Activities }\end{array}$ & $\begin{array}{c}\text { Not } \\
\text { Informative }\end{array}$ & $\begin{array}{l}\text { Prior to SOP } 98-5 \text { some companies were expensing start-up costs while } \\
\text { other companies were capitalizing them, using a variety of periods over } \\
\text { which to amortize the costs. The disparate treatment of these costs } \\
\text { diminished the comparability of companies' financial statements. This } \\
\text { standard sought to bring uniformity to the treatment of start-up and } \\
\text { organization costs by dictating that these costs be expensed as incurred. } \\
\text { Similar to reasoning discussed for EITF } 97-13 \text {, expensing such costs is } \\
\text { unlikely to provide managers with information to facilitate investment. }\end{array}$ \\
\hline $\begin{array}{l}\text { SAB 101: } \\
\text { Revenue } \\
\text { Recognition in } \\
\text { Financial } \\
\text { Statements }\end{array}$ & $\begin{array}{c}\text { Not } \\
\text { Informative }\end{array}$ & $\begin{array}{l}\text { This statement required that revenue should not be recognized until it is } \\
\text { realized or realizable and earned. For revenue to be realized or realizable } \\
\text { and earned there should be persuasive evidence that an arrangement } \\
\text { exists, delivery should have occurred or services should be rendered, the } \\
\text { seller's price to the buyer should be fixed or determinable, and } \\
\text { collectability should be reasonably assured. The primary result of this } \\
\text { statement was to postpone revenue recognition until a higher verifiability } \\
\text { threshold had been met. Since managers are less likely to gain knowledge } \\
\text { about the cash flow stream from a higher verifiability threshold, this } \\
\text { standard is less likely to provide managers with new information. In fact, } \\
\text { Altamuro et al. (2005) find that the association between earnings and } \\
\text { future cash flows and, between unexpected earnings and earnings } \\
\text { announcement period returns declined after the adoption of SAB } 101 \\
\text { suggesting that there might have been a loss in earnings informativeness. }\end{array}$ \\
\hline $\begin{array}{l}\text { SFAS No. } \\
133 / 138: \\
\text { Accounting for } \\
\text { Derivative } \\
\text { Instruments and } \\
\text { Hedging } \\
\text { Activities }\end{array}$ & $\begin{array}{c}\text { Not } \\
\text { Informative }\end{array}$ & $\begin{array}{l}\text { This statement requires that an entity recognize all derivatives as either } \\
\text { assets or liabilities in the statement of financial position and measure } \\
\text { those instruments at fair value. If certain conditions are met, a derivative } \\
\text { may be specifically designated as hedge. When an entity applies hedge } \\
\text { accounting, changes in the fair value of the derivative instrument can be } \\
\text { offset with changes in the fair value of the asset/liability being hedged. } \\
\text { Before the issuance of this Statement, many derivatives were "off-balance- } \\
\text { sheet" because, unlike conventional financial instruments such as stocks } \\
\text { and bonds, derivatives often reflect at their inception only a mutual } \\
\text { exchange of promises with little or no transfer of tangible consideration. } \\
\text { Although SFAS } 133 \text { and } 138 \text { substantially changed accounting for } \\
\text { derivatives, I do not expect this rule change to provide managers with } \\
\text { new information. First, derivative instruments often have readily available } \\
\text { market prices that are used to determine the value of the derivative assets } \\
\text { or liabilities and do not require managers to make any estimates. Further, } \\
\text { choosing the appropriate derivative instrument, whether for speculation } \\
\text { or for hedging, requires a reasonable prior understanding of the } \\
\text { associated risks and payoffs. Recognizing derivatives on financial } \\
\text { statements is unlikely to change a manager's ability to assess the risks and } \\
\text { payoffs from investing in derivative instruments. }\end{array}$ \\
\hline $\begin{array}{l}\text { SFAS No. 142: } \\
\text { Goodwill and } \\
\text { Other Intangible } \\
\text { Assets }\end{array}$ & Informative & $\begin{array}{l}\text { This standard addresses accounting for acquired goodwill and other } \\
\text { intangible assets. Prior to this standard goodwill and other intangibles } \\
\text { were amortized over an arbitrary period with an arbitrary ceiling of } 40 \\
\text { years even if the asset had an indefinite life. This standard required firms } \\
\text { to do away with amortization of assets with indefinite lives and conduct }\end{array}$ \\
\hline
\end{tabular}




\begin{tabular}{|c|c|c|}
\hline & & $\begin{array}{l}\text { impairment tests at least annually. Impairment tests require firms to } \\
\text { compare the book value of net assets to the fair value of the related } \\
\text { operations. To get a reasonable estimate of the fair value, firms are likely } \\
\text { to need information about the expected future cash flows generated from } \\
\text { the assets and the risk associated with those expected cash flows (as } \\
\text { outlined in Statement of Financial Accounting Concepts } 7 \text {, Using Cash } \\
\text { Flow Information and Present Value in Accounting). Such an activity has } \\
\text { the potential for providing managers with new information useful for } \\
\text { evaluating investment decisions. Although number of studies show that } \\
\text { managers use the discretion allowed by SFAS } 142 \text { opportunistically (e.g., } \\
\text { Ramanna and Watts (2010), such behavior is not indicative of whether } \\
\text { the internal estimates of the value of goodwill used by managers } \\
\text { improved or worsened. To the extent manager fear litigation risk, they } \\
\text { are more likely to back their estimates of the value of goodwill with more } \\
\text { information after the adoption of SFAS } 142 \text { than before, even if they do } \\
\text { not disclose the information in financial statements. }\end{array}$ \\
\hline $\begin{array}{l}\text { SFAS No. 143: } \\
\text { Accounting for } \\
\text { Asset Retirement } \\
\text { Obligations }\end{array}$ & Informative & $\begin{array}{l}\text { SFAS } 143 \text { established accounting standards for the recognition and } \\
\text { measurement of obligations attributable to the removal of assets as well as } \\
\text { to their associated restoration costs. Since the obligation must be } \\
\text { recorded at fair value and an active market for these obligations generally } \\
\text { does not exist, the company must use the expected present value } \\
\text { technique outlined in Statement of Financial Accounting Concepts } 7 \text {, } \\
\text { Using Cash Flow Information and Present Value in Accounting, which } \\
\text { results in measuring the asset's and related liability's present value by } \\
\text { using each company's credit-adjusted rate. Inherent in the calculation of } \\
\text { the obligation and its related asset cost are numerous assumptions and } \\
\text { judgments, including the estimated life of the property to be retired, } \\
\text { settlement amounts, inflation factors, credit-adjusted discount rates, } \\
\text { timing of settlement, and changes in the legal, regulatory, and } \\
\text { environmental landscapes. These assumptions and judgments require the } \\
\text { assimilation of information which likely also helps firms re-evaluate } \\
\text { investment decisions. }\end{array}$ \\
\hline $\begin{array}{c}\text { FIN 47: } \\
\text { Accounting for } \\
\text { Conditional } \\
\text { Asset Retirement } \\
\text { Obligations }\end{array}$ & Informative & $\begin{array}{l}\text { This Interpretation clarifies the term conditional asset retirement } \\
\text { obligation as used in SFAS } 143 \text {. } \\
\text { Many companies concluded that SFAS } 143 \text { did not apply to } \\
\text { "conditional" Asset Retirement Obligations (AROs). "Conditional" is } \\
\text { defined by the FASB as "the legal obligation to perform an asset } \\
\text { retirement activity in which the timing and/or method of settlement is } \\
\text { conditioned on a future event that may not be in the control of the } \\
\text { entity." FIN } 47 \text { was promulgated to clarify the term "conditional," as } \\
\text { used in SFAS } 143 \text {. FIN } 47 \text { makes it clear that if a company has sufficient } \\
\text { information to reasonably estimate the fair value of an ARO, it must so } \\
\text { recognize at the time the liability is incurred, even if the timing for the } \\
\text { retirement of the asset remains uncertain. For example, if a building is } \\
\text { purchased by an entity that eventually must meet certain environmental } \\
\text { cleanup regulations the entity must record those cleanup costs when the } \\
\text { asset is acquired and as soon as the costs for cleanup may be estimated. } \\
\text { Effectively, FIN } 47 \text { requires that companies disaggregate their } \\
\text { environmental liabilities by placing these liabilities on the balance sheet } \\
\text { before they become certainties, so shareholders can get a better sense of } \\
\text { the company's value. According to FIN } 47 \text {, an asset is reasonably }\end{array}$ \\
\hline
\end{tabular}




\begin{tabular}{|c|c|c|}
\hline & & $\begin{array}{l}\text { estimable if: (1) it is evident that the fair value of the obligation is } \\
\text { embodied in the acquisition price of the asset; }(2) \text { an active market exists } \\
\text { for the transfer of the obligation; or ( } 3 \text { ) sufficient information exists to } \\
\text { apply an expected present value technique. There is "sufficient } \\
\text { information" available to reasonably estimate the cost of an ARO when a } \\
\text { settlement date is known or the date or method of settlement is } \\
\text { reasonably estimable. If there is not sufficient information available, an } \\
\text { ARO is not recognized, but the entity still must submit a report with its } \\
\text { financial statement detailing why there is not sufficient information } \\
\text { available. Given the amount of judgment and estimation required by this } \\
\text { pronouncement, I classify this interpretation as providing information. }\end{array}$ \\
\hline $\begin{array}{l}\text { FIN 46/46r: } \\
\text { Consolidation of } \\
\text { variable interest } \\
\text { entities }\end{array}$ & $\begin{array}{c}\text { Not } \\
\text { Informative }\end{array}$ & $\begin{array}{l}\text { Accounting Research Bulletin (ARB) 51-Consolidated Financial } \\
\text { Statements-requires that an enterprise's consolidated financial } \\
\text { statements include subsidiaries in which the enterprise has a controlling } \\
\text { financial interest. That requirement usually has been applied to } \\
\text { subsidiaries in which an enterprise has a majority voting interest, but in } \\
\text { many circumstances the enterprise's consolidated financial statements do } \\
\text { not include variable interest entities with which it has similar } \\
\text { relationships. This statement was issued because the voting interest } \\
\text { approach is not effective in identifying controlling financial interests in } \\
\text { entities that are not controllable through voting interests or in which the } \\
\text { equity investors do not bear the residual economic risks. This statement } \\
\text { spells out the conditions under which an entity should be consolidated. } \\
\text { Since the specific criteria to consolidate do not require extensive } \\
\text { information collection, managerial judgments, or estimates, I do not } \\
\text { expect this standard to inform manager about investment. }\end{array}$ \\
\hline $\begin{array}{l}\text { SFAS No. 123r: } \\
\text { Share-based } \\
\text { payment } \\
\text { (revised) }\end{array}$ & $\begin{array}{c}\text { No } \\
\text { Information }\end{array}$ & $\begin{array}{l}\text { This Statement requires a public entity to measure the cost of employee } \\
\text { services received in exchange for an award of equity instruments based on } \\
\text { the grant-date fair value of the award (with limited exceptions). That cost } \\
\text { is recognized over the period during which an employee is required to } \\
\text { provide service in exchange for the award-the requisite service period } \\
\text { (usually the vesting period). This Statement eliminates the alternative to } \\
\text { use Opinion } 25 \text { 's intrinsic value method of accounting that was provided } \\
\text { in Statement } 123 \text { as originally issued. Under Opinion } 25 \text {, issuing stock } \\
\text { options to employees generally resulted in recognition of no } \\
\text { compensation cost. Since SFAS } 123 \text { already required firms to disclose the } \\
\text { fair value of equity based compensation, implementation of SFAS } 123 \mathrm{r} \text { is } \\
\text { unlikely to provide managers with information to facilitate investment } \\
\text { decisions. }\end{array}$ \\
\hline
\end{tabular}




\section{APPENDIX B}

\section{Variable Definitions}

\begin{tabular}{|c|c|}
\hline Variable Name & Variable Definitions with Compustat or CRSP codes in paranthesis \\
\hline $\begin{array}{l}\text { Cumulative } \\
\text { Effect }\end{array}$ & $\begin{array}{l}\text { Cumulative Effect (ACCHG) is the cumulative effect of an accounting change as reported } \\
\text { in the income statement, deflated by average assets in period t and } t-1 \text {. It represents effect } \\
\text { of company adjustments due to accounting changes on prior period earnings. }\end{array}$ \\
\hline $\begin{array}{l}\text { Capital } \\
\text { Expenditure }\end{array}$ & $\begin{array}{l}\text { Capital Expenditure (CAPX) is the cash outflow or the funds used for additions to the } \\
\text { company's property, plant and equipment, excluding amounts arising from acquisitions, } \\
\text { reported in the Statement of Cash Flows, deflated by average assets in period t and t- } 1 \text {. }\end{array}$ \\
\hline $\begin{array}{l}\mathrm{R} \& \mathrm{D} \\
\text { Expenditure }\end{array}$ & $\begin{array}{l}\text { RED Expenditure (XRD) is the cost incurred during the year that relate to the development } \\
\text { of new products or services, deflated by average assets in period } t \text { and } t-1 . R \& D \\
\text { Expenditure is coded to zero if it is missing. }\end{array}$ \\
\hline Tobin's Q & $\begin{array}{l}\text { Tobin's } Q \text { is measured as the sum of market value of equity (PRCC_F x CSHO), short } \\
\text { term debt (DLC) and long term debt (DLTT) divided by total assets (AT). }\end{array}$ \\
\hline Growth & $\begin{array}{l}\text { Growth is the change in total assets (AT) from period } t-1 \text { to period } t \text { scaled by total assets } \\
\text { (AT) in period } t-1 \text {. }\end{array}$ \\
\hline Ln(Age) & $\begin{array}{l}\text { Ln(Age) is the natural logarithm of the difference between the first year the firm enters } \\
\text { Compustat and the current year. }\end{array}$ \\
\hline $\begin{array}{l}\text { Ln(Market Value } \\
\text { of Equity) }\end{array}$ & $\begin{array}{l}\text { Ln(Market Value of Equity) is the natural logarithm stock price at the end of the year } \\
\text { (PRCC_F) times the number of shares outstanding (CSHO). }\end{array}$ \\
\hline $\mathrm{CFO}$ & $\begin{array}{l}\text { CFO (OANCF) is cash flows from operations reported in the statement of cash flows, } \\
\text { deflated by average assets in period } t \text { and } t-1 \text {. }\end{array}$ \\
\hline Cash & $\begin{array}{l}\text { Cash }(\mathrm{CHE}) \text { is cash and all securities readily transferable to cash, deflated by average assets } \\
\text { in period } \mathrm{t} \text { and } \mathrm{t}-1 \text {. }\end{array}$ \\
\hline Leverage & $\begin{array}{l}\text { Leverage is sum of short term debt (DLC) and long term debt (DLTT), deflated by average } \\
\text { assets in period } t \text { and } t-1 \text {. }\end{array}$ \\
\hline Stock Returns & $\begin{array}{l}\text { Stock Returns (RET) in the total returns from investing in the stock of a company from } \\
\text { period t- } 1 \text { to period t. }\end{array}$ \\
\hline $\begin{array}{l}\text { Information/No } \\
\text { Information }\end{array}$ & $\begin{array}{l}\text { Information is a dummy variable which takes on the value of one for observations in which } \\
\text { the firm adopted an accounting standard which is likely to inform managers about current } \\
\text { or future investment opportunities. It takes on the value of zero otherwise. The accounting } \\
\text { standards classification is described in Appendix A. No Information is a dummy variable } \\
\text { which takes on the value of one (zero) if Information equals zero (one). }\end{array}$ \\
\hline $\begin{array}{l}\text { Organizational } \\
\text { Complexity Index }\end{array}$ & $\begin{array}{l}\text { The sum of the square of firm sales in each business segment divided by the square of total } \\
\text { sales multiplied by minus one. Segment data are obtained from the Compustat Business } \\
\text { Industry Segment file. Firms missing from the segment file are assumed to be single } \\
\text { segment firms (i.e., the complexity index is coded to -1). }\end{array}$ \\
\hline
\end{tabular}




\begin{tabular}{|c|c|}
\hline Variable Name & Variable Definitions \\
\hline $\begin{array}{l}\Delta \text { Institutional } \\
\text { Ownership }\end{array}$ & $\begin{array}{l}\text { The change in the percentage of firms' shares held by institutional investors after the } \\
\text { change in GAAP (i.e., change from t-1 to t). Institutional Ownership is assumed to be zero } \\
\text { if the data are missing. Ownership data are obtained from the Thomson-Reuter's } \\
\text { Institutional Holdings (13F) Database. }\end{array}$ \\
\hline $\begin{array}{l}\Delta \text { Number of } \\
\text { Analysts }\end{array}$ & $\begin{array}{l}\text { The change in the number of analysts (NUMEST) following the firm as provided by IBES } \\
\text { after the change in GAAP (i.e., change from t- } 1 \text { to t). Analyst following is assumed to be } \\
\text { zero if the firm is not covered by IBES. }\end{array}$ \\
\hline $\begin{array}{l}\Delta \text { Financial } \\
\text { Reporting } \\
\text { Quality }\end{array}$ & $\begin{array}{l}\text { The change in the Dechow and Dichev (2002) measure of reporting quality with the } \\
\text { McNichols (2002) suggested modification, around the change in GAAP. Specifically, I } \\
\text { estimate a regression of current accruals on past, current, and future cash flows, the } \\
\text { change in sales, and gross PP\&E for each industry/year pool using all firms in Compustat } \\
\text { and the Fama-French } 30 \text { industry classification scheme. The absolute value of the residual } \\
\text { multiplied by minus one is my measure of reporting quality (for each firm-year). Since the } \\
\text { Dechow-Dichev measure uses past and future cash flow data, I compute the change in } \\
\text { reporting quality as reporting quality in period t } 1 \text { minus reporting quality in period t- } \\
\text { Missing observations are assumed to have no change in reporting quality. However, my } \\
\text { inferences are unchanged without this assumption. }\end{array}$ \\
\hline $\begin{array}{l}\Delta \text { Capital } \\
\text { Expenditure } \\
\text { (Total } \\
\text { Investment) } \\
\text { Efficiency - Sales } \\
\text { Growth }\end{array}$ & $\begin{array}{l}\text { Capital Expenditure (Total Investment) efficiency is the change in the absolute value of } \\
\text { the residuals from a regression of capital expenditure (capital }+R \& D \text { expenditure) in } \\
\text { period } t \text { on sales growth in period } t-1 \text {. The regression is estimated for each industry/year } \\
\text { pool using all firms in Compustat and the Fama-French } 30 \text { industry classification scheme. } \\
\text { The change in efficiency is the difference between the residual in period } t+1 \text { and } t- \\
\text { period } t \text { is the year of the accounting change. I multiply the measure by minus one so that } \\
\text { a larger number indicates more efficient investment. }\end{array}$ \\
\hline $\begin{array}{l}\Delta \text { Capital } \\
\text { Expenditure } \\
\text { (Total } \\
\text { Investment) } \\
\text { Efficiency - Q }\end{array}$ & $\begin{array}{l}\text { Capital Expenditure (Total Investment) efficiency is the change in the absolute value of } \\
\text { the residuals from a regression of capital expenditure (capital }+R \& D \text { expenditure) in } \\
\text { period } t \text { on Tobin's } Q \text { in period } t-1 \text { and cash flows in period } t \text {. The regression is estimated } \\
\text { for each industry/year pool using all firms in Compustat and the Fama-French } 30 \text { industry } \\
\text { classification scheme. The change in efficiency is the difference between the residual in } \\
\text { period } t+1 \text { and } t-1 \text {; period } t \text { is the year of the accounting change. I multiply the measure by } \\
\text { minus one so that a larger number indicates more efficient investment. }\end{array}$ \\
\hline Deal Scan & $\begin{array}{l}\text { Deal Scan is a dummy variable which takes on the value of one (zero) if the firm has (does } \\
\text { not have) data available in the Dealscan database for year } t \text {. }\end{array}$ \\
\hline
\end{tabular}




\begin{tabular}{|l|l|}
\hline Variable Name & \multicolumn{1}{|c|}{ Variable Definitions with Compustat or CRSP codes in paranthesis } \\
\hline $\begin{array}{l}\text { Covenant/No } \\
\text { Covenant }\end{array}$ & $\begin{array}{l}\text { Covenant is a dummy variable which takes on the value of one (zero) if the observation has } \\
\text { (does not have) at least one financial covenant which is likely to be affected by the } \\
\text { cumulative effect of an accounting change. No Covenant is a dummy variable which takes } \\
\text { on the value of one (zero) if Covenant equals zero (one). }\end{array}$ \\
\hline $\begin{array}{l}\text { Contracts with } \\
\text { Fixed GAAP }\end{array}$ & $\begin{array}{l}\text { Contracts with Fixed GAAP is a dummy variable which takes on the value of one (zero) if } \\
\text { the debt contract is based on Fixed GAAP. The Fixed GAAP practice excludes all changes } \\
\text { to GAAP including mandatory accounting changes once the debt contract is signed. }\end{array}$ \\
\hline $\begin{array}{l}\text { Contracts with } \\
\text { Hybrid GAAP }\end{array}$ & $\begin{array}{l}\text { Contracts with Hybrid GAAP is a dummy variable which takes on the value of one (zero) if } \\
\text { the debt contract is based on Hybrid GAAP. The Hybrid GAAP gives lenders and } \\
\text { borrowers a mutual option to freeze GAAP at any point in time. }\end{array}$ \\
\hline $\begin{array}{l}\text { Contracts with } \\
\text { Floating GAAP }\end{array}$ & $\begin{array}{l}\text { Contracts with Floating GAAP is a dummy variable which takes on the value of one (zero) if } \\
\text { the debt contract is based on Floating GAAP. The Floating GAAP practice uses the most } \\
\text { up-to-date version of GAAP to determine compliance with the terms of the contract. }\end{array}$ \\
\hline $\begin{array}{l}\text { Fisclose } \\
\text { Reconciliation } \\
\text { No Floating } \\
\text { GAAP }\end{array}$ & $\begin{array}{l}\text { Disclose Reconciliation is a dummy variable which equals one (zero) if the debt contract } \\
\text { requires the firm to reconcile and disclose differences in financial ratios after changes in } \\
\text { GAAP while renegotiating covenants. }\end{array}$ \\
\hline $\begin{array}{l}\text { Floating GAAP is a dummy variable which takes on the value of one if the debt agreement } \\
\text { the old and new accounting practice while renegotiating covenants to adjust for the } \\
\text { change in GAAP. No Floating GAAP is a dummy variable which takes on the value of one } \\
\text { (zero) if Floating GAAP equals zero (one). }\end{array}$ \\
\hline
\end{tabular}




\section{BIBLIOGRAPHY}

Acharya, V., H. Almeida, and M. Campello, 2007, Is cash negative debt? A hedging perspective on corporate financial policies, Journal of Financial Intermediation 16, 515 554.

Adam, T., and V. Goyal, 2008. The investment opportunity set and its proxy variables. Journal of Financial Research Spring, 41-63.

Ai, C., and E. C. Norton. 2003. Interaction Terms in Logit and Probit Models. Economics Letters, 80(1): 12 3-29.

Altamuro, J., A. Beatty, and J.P. Weber, 2005. The effects of accelerated revenue recognition on earnings management and earnings informativeness: Evidence from SEC Staff Accounting Bulletin No. 101. The Accounting Review 80, 373-401.

Amir, E., 1993. The market valuation of accounting information: The case of postretirement benefits other than pensions. The Accounting Review 68, 703-724.

Armstrong C.S., W.R. Guay, and J.P. Weber. 2010. The Role of Information and Financial Reporting In Corporate Governance and Debt Contracting. Journal of Accounting and Economics, forthcoming. 
Ayers, B., 1998. Deferred tax accounting under SFAS No.109: An empirical investigation of its incremental value-relevance relative to APB No.11.The Accounting Review 73, 195212.

Ball, R., 1980. Discussion of Accounting for Research and Development Costs: The Impact on Research and Development Expenditures. Journal of Accounting Research 18 Supplement: $27-37$.

Ball, R., 2004. Corporate Governance and Financial Reporting at Daimler-Benz (Daimler Chrysler) AG: From a 'Stakeholder' Toward a 'Shareholder Value' Model. The Economics and Politics of Accounting: International Perspectives on Research, Trends, Policy, and Practice, edited by A. Hopwood, C. Leuz, and D. Pfaff. Publisher Location: Oxford University Press, 103-43.

Balsam, S., I. Haw, and S.B. Lilien, 1995. Mandatory accounting changes and managerial discretion. Journal of Accounting and Economics 20 (1), 3-29.

Beatty, A., 1995. Fair value accounting: how fair is it? St. Louis Federal Review.

Beatty, A., 2007. How does changing measurement change management behavior? A review of the evidence. Accounting and Business Research Special Issue: International Accounting Policy Forum pp. 63-71. 
Beatty, A., K. Ramesh, and J. Weber, 2002. The importance of accounting changes in debt contracts: the cost of flexibility in covenant calculations. Journal of Accounting and Economics, 33(2):173-204.

Beatty, A., and Weber, J., 2006. Accounting discretion in fair value estimates: an examination of SFAS 142 goodwill impairments. Journal of Accounting Research 44, 257 288.

Beaver, W., 1981. Financial Reporting: An Accounting Revolution, Englewood Cliffs, NJ: Prentice Hall.

Bens, D. A. and S. J. Monahan. 2008. Altering investment decisions to manage financial reporting outcomes: asset-backed commercial paper conduits and FIN 46. Journal of Accounting Research 46 (5):1017-1055.

Bens, D., V. Nagar, F. M.H. Wong, 2002. Real investment implications of employee stock option exercises. Journal of Accounting Research 40, 359-393.

Bhat, G., R. Frankel, and X. Martin, 2010. Panacea, Pandora's Box, or Placebo: Feedback in Bank Mortgage-based Security Holdings and Fair Value Accounting. Washington University working paper.

Biddle, G. and G. Hillary, 2006, Accounting quality and firm-level capital investment, The Accounting Review 81, 963-982. 
Biddle, G., G. Hillary, and R. Verdi, 2009, How does financial reporting quality relate to investment efficiency?, Journal of Accounting and Economics 48, 112-131.

Brennan, M., 2003, Corporate investment policy. In G.M. Constantinides, M. Harris \& R.M. Stulz, eds., Corporate Finance, vol. 21, 1A of Handbook of the Economics of Finance, Elsevier, Amsterdam.

Bushee, B. J. 1998, The influence of institutional investors on myopic $R \& D$ investment behavior. The Accounting Review 73(3), 305-333.

Bushman, R., Q. Chen, E. Engel., and A. Smith, 2004. Financial accounting information, organizational complexity and corporate governance systems. Journal of Accounting and Economics 37, 167-201.

Cameron, A. C., J. B. Gelbach, and D. L. Miller, 2010, Robust inference with multi-way clustering. Journal of Business $\mathcal{E}$ Economic Statistics. forthcoming

Carey, M., and M. Hrycray, 1999, Credit flow, risk, and the role of private debt in capital structure, Working paper, Federal Reserve Board.

Chava, S. and M. Roberts, 2008. How does financing impact investment? The role of debt covenant violations. Journal of Finance 63, 2085-2121.

Choudhary, P., M. Venkatachalam, S. Rajgopal. 2009. Accelerated Vesting of Employee Stock Options in Anticipation of FAS 123-R, Journal of Accounting Research 47(1): 105146. 
Christensen, H.B., E. Lee, and M. Walker. 2009. Do IFRS reconciliations convey information? The effect of debt contracting. Journal of Accounting Research 47: 11671199

Christensen, H. B., and V. Nikolaev. 2009. Contracting on Mandatory Changes to GAAP: New Practice and its Determinants. University of Chicago working paper.

Cohen, D. A., R. Mashruwala, and T. Zach. 2009. The Use of Advertising Activities to Meet Earnings Benchmarks: Evidence from Monthly Data. Review of Accounting Studies, Forthcoming.

Collins, D. W., M. S. Rozeff and D. S. Dhaliwal, 1981, A cross-sectional analysis of the economic determinants of market reaction to proposed mandatory accounting changes in the oil and gas industry, Journal of Accounting and Economics, March, 37-72.

Cragg, J.G., 1971. Some statistical models for limited dependent variables with applications to the demand for durable goods. Econometrica 39, pp. 829-844.

Dechow, P., and I. Dichev. 2002. The quality of accruals and earnings: The role of accrual estimation errors. The Accounting Review 77 (Supplement): 35-59.

Dechow, P., and D. Skinner, 2000. Earnings management: reconciling the views of accounting academics, practitioners, and regulators. Accounting Horizons 14 (2), 235250. 
Dechow, P., and R. Sloan, 1991. Executive incentives and the horizon problem: an empirical investigation. Journal of Accounting and Economics 14, 51-89.

Dichev, I. D., and D. Skinner, 2002, Large sample evidence on the debt covenant hypothesis, Journal of Accounting Research 40, 1091-1123.

Drury, C., and M. Tayles. 1997., Evidence on the Financial Accounting Mentality Debate: A Research Note. British Accounting Review 29: 263-76.

Durnev, A., and C. Mangen, 2009, Corporate investments: Learning from restatements, Journal of Accounting Research 47, 679-720.

Financial Accounting Standards Board (FASB). 1978. Statement of Financial Accounting Concepts No. 1: Objectives of Financial Reporting by Business Enterprises. http://www.fasb.org/pdf/aop CON1.pdf

Financial Accounting Standards Board (FASB). 1990. Statement of Financial Accounting Standards No. 106 Employers' Accounting for Postretirement Benefits Other Than Pensions. http://www.fasb.org/pdf/fas106.pdf

Financial Accounting Standards Board (FASB). 2003. FASB Interpretation No. 46 Consolidation of Variable Interest Entities - an interpretation of ARB No. 51.. http://www.fasb.org/pdf/fin\%2046.pdf 
Financial Accounting Standards Board (FASB). 2005. Statement of Financial Accounting Standards No. 154 Accounting Changes and Error Corrections a replacement of APB Opinion No. 20 and FASB Statement No. 3. http://www.fasb.org/pdf/aop FAS154.pdf

Fazzari, S. M., R. G. Hubbard, and B. C. Petersen, 1988. Financing Constraints and Corporate Investment. Brookings Papers Econ. Activity, no. 1, pp. 141-95.

Fields, T., T. Lys, L. Vincent, 2001. Empirical research on accounting choice. Journal of Accounting and Economics 31, 255-308.

Frankel, R.M., S.P. Kothari, and J.P. Weber, 2006. Determinants of the informativeness of analyst research. Journal of Accounting and Economics 41, 29-54.

Gaver, J.J. and K.M. Gaver, 1998. The relation between nonrecurring accounting transactions and CEO cash compensation. The Accounting Review 73 (2), 235-253.

Gow, I.D., G. Ormazabal., D.J. Taylor. 2010. Correcting for cross-sectional and time-series dependence in accounting research. The Accounting Review 85, 483-512.

Graham, J. R., and C. Harvey, 2001. The theory and practice of corporate finance: evidence from the field. Journal of Financial Economics 60, 187-243.

Graham, J. R., C. Harvey, and S. Rajgopal, 2005, The economic implications of corporate financial reporting, Journal of Accounting and Economics 40, 3-73. 
Graham, J., M. Hanlon, and T. Shevlin., 2010. Real Effects of Accounting Rules: Evidence from Multinational Firms' Investment Location and Profit Repatriation Decisions. Journal of Accounting Research, forthcoming.

Greene W., 2003. Econometric Analysis. Englewood Cliffs, NJ: Prentice-Hall.

Healy, P. M., and J. M. Wahlen. 1999. A review of the earnings management literature and its implications for standard setting. Accounting Horizons 13: 365-383.

Hemmer, T. and E. Labro., 2008. On the Optimal Relation between the Properties of Managerial and Financial Reporting Systems. Journal of Accounting Research, 46, 12091240.

Hentschel, L. and S.P. Kothari, 2001. Are corporations reducing or taking risks with derivatives? Journal of Financial and Quantitative Analysis 36, 93-118.

Hodder, L., M. Kohlbeck, and M.L. McAnally. 2002. Accounting Choices and Risk Management: SFAS 115 and U.S. Bank Holding Companies. Contemporary Accounting Research 19: 225- 270

Holthausen, R. and R. Leftwich, 1983. The economic consequences of accounting choice: implications of costly contracting and monitoring. Journal of Accounting and Economics 5, $77-117$. 
Hopper, T., L. Kirkham, R. W. Scapens, and S. Turley., 1992. Does Financial Accounting Dominate Management Accounting? A Research Note. Management Accounting Research $307-11$.

Hoshi, T., A. Kashyap, and D. Scharfstein. 1991. Corporate structure, liquidity and investment: Evidence from Japanese industrial groups. The Quarterly Journal of Economics 106 (1): 33-60.

Imhoff, E. and J. Thomas, 1988. Economic consequences of accounting standards: the lease disclosure rule change. Journal of Accounting and Economics 10, 277-310.

Jackson, S.B., X. Liu, and M. Cecchini. 2009. Economic consequences of firms' depreciation method choice: Evidence from capital investments. Journal of Accounting and Economics 48, 54-68.

Johnson, H. T., and R. S. Kaplan. 1987. Relevance Lost: Rise and Fall of Management Accounting. Boston, MA: Harvard Business School Press.

Kahan, M. and B. Tuckman, 1993. Private vs. public lending: Evidence from covenants, Working paper, Anderson Graduate School of Management, UCLA.

Kanodia, C. 2007. Accounting disclosure and real effects, Foundations and Trends in Accounting, Now Publishers Inc. ISBN 978-1-60198-062-5, vol. 1, no. 3, pp. ix, 95.

Kaplan R. S., 1984. The Evolution of Management Accounting. The Accounting Review, 59, $390-418$. 
Kothari, S.P., K. Ramanna, and D. Skinner, 2010, Implications for GAAP from an Analysis of Positive Research in Accounting. Journal of Accounting and Economics, forthcoming.

Lee, L. 2010. Incentives to inflate reported cash from operations using classification and timing. Working paper, Boston College.

Leftwich, R., 1981, Evidence on the impact of mandatory changes in accounting principles in corporate loan agreements, Journal of Accounting and Economics 3, 3-36.

Lys, T., 1984. Mandated accounting changes and debt covenants: the case of oil and gas accounting. Journal of Accounting and Economics 9, 39-66.

Maddala, G.S., 1991. A perspective on the use of limited-dependent variables models in accounting research. The Accounting Review 66 (4), 788-807.

Marquardt, C. and C. Wiedman 2007. Economic consequences of financial reporting changes: diluted EPS and contingent convertible securities. Review of Accounting Studies 12: 487-523.

McNichols, M. 2002. Discussion of the Quality of Accruals and Earnings: The Role of Accrual Estimation Errors. The Accounting Review 77 (Supplement): 61-69.

McNichols, M., and S. Stubben, 2008. Does earnings management affect firms' investment decisions? The Accounting Review 83 (6), 1571-1603. 
Miller, G., and D. Skinner, 1998. Determinants of the valuation allowance for deferred tax assets under SFAS No. 109. The Accounting Review 73, 213-233.

Mittelstaedt, F., W. Nichols, and P. Regier, 1995. SFAS No. 106 and benefit reductions in employer-sponsored retiree health care plans. The Accounting Review 70 (4),535-556.

Mohrman, M.B., 1996. The use of fixed GAAP provisions in debt contracts. Accounting Horizons, 10:78-91.

Murphy, K.J., and J.L. Zimmerman, 1993. Financial performance surrounding CEO turnover. Journal of Accounting and Economics 16 (1/2/3), 273-315.

Nini, G., D. Smith, and A. Sufi, 2009, Creditor control rights and firm investment policy, Journal of Financial Economics 93, 159-184.

Petersen, M. A., 2009, Estimating standard errors in finance panel data sets: Comparing approaches, Review of Financial Studies 22, 435-480.

Plantin, G., H. Sapra, and H.S. Shin, 2008. Marking-to-Market: Panacea or Pandora's box? Journal of Accounting Research 46 (2), 435-460.

Powell, J.L., 1984. Least absolute deviations estimation for the censored regression model. Journal of Econometrics 25, pp. 303-325. 
Ramanna, K., 2008. The implications of unverifiable fair-value accounting: Evidence from the political economy of goodwill accounting. Journal of Accounting and Economics 45: 253-281.

Ramanna, K., and R. Watts, 2010. Evidence from goodwill non-impairments on the effects of using unverifiable estimates in financial reporting. Working Paper, Harvard Business School.

Revsine, L., D. Collins, and W. B. Johnson. 1999. Financial Reporting and Analysis. Upper Saddle River, NJ: Prentice Hall.

Richardson, S., 2006, Over-investment of free cash flow. Review of Accounting Studies 11, 159-189.

Roychowdhury, S. 2006, Earnings management through real activities manipulation. Journal of Accounting and Economics 42(3), 335-370.

Sapra, H., 2010. The Economic Trade-offs in the Fair Value Debate. Journal of Law, Economics, and Policy, Spring, 193-218.

Securities and Exchange Commission (SEC). 1999. Revenue Recognition. Staff Accounting Bulletin No. 101. Washington, D.C.: Government Printing Office.

Simon, H. A., 1973. Applying Information Technology to Organization Design. Public Administration Review, 106, 467-482. 
Sims, C., 2003. Implications of Rational Inattention. Journal of Monetary Economics 50(3), $665-90$.

Singh, L., 2001. Profiting from health-care cuts? CFO: Magazine for Senior Financial Executives.

Smith, C., and J. Warner, 1979. On financial contracting: an analysis of bond covenants. Journal of Financial Economics 7, 117-161.

Sweeney, A. P., 1994, Debt covenant violations and managers' accounting responses, Journal of Accounting and Economics 17, 281-308.

Tirole, J. 2006. The Theory of Corporate Finance. Princeton, NJ: Princeton University Press.

Tobin, J. 1958. Estimation of Relationships for Limited Dependent Variables, Econometrica $26,24-36$.

Verde, M., 1999. Loan preserve: The value of covenants, Fitch IBCA loan products special report, available at www.fitchibca.com

Watts, R.L. and J.L. Zimmerman, 1986, Positive accounting theory (Prentice Hall: Englewood Cliffs, NJ).

Whited, T. M., 2006, External finance constraints and the intertemporal pattern of intermittent investment, Journal of Financial Economics 81, 467-502. 
Wooldridge, J., 2002. Econometric Analysis of Cross Section and Panel Data. Cambridge, MA: MIT Press.

Wurgler, J., 2000, Financial markets and the allocation of capital, Journal of Financial Economics 58, 187-214.

Zhang, J. 2009. Economic consequences of recognizing off-balance sheet activities. Working Paper.

Zimmerman, J. L., 2009. Accounting for decision making and control (6 ${ }^{\text {th }}$ ed.). Irwin $/$ McGraw Hill Publishing Company, New York, NY. 